\title{
RESEÑA DE SENTENCIAS DEL TRIBUNAL SUPREMO (Segundo trimestre de 1990)
}

\author{
POR \\ Ma del Rosario ALONSO IBAÑez \\ UNIVERSIDAD DE OVIEDO
}

Sumario: I. Fuentes. II. Organizacion administrativa. III. Haciendas locales. IV. Empleo publico. V. Actos administrativos. VI. Contratos. VII. SANCIONES. VIII. RESPONSABILIDAD PATRIMONIAL. IX. EXPRopiacion fORZOSa. X. Bienes. XI. Servicio publicos. XII. Urbanismo.

\section{I.- FUENTES}

I. Normas comunitarias. Tasa de corresponsabilidad en el sector de los productos lácteos. Reglamentos comunitarios: distinción en orden a su aplicación directa. Desde la incorporación de España al Mercado Común Europeo existe la obligación de retener el importe de la tasa, exigible a toda empresa compradora de la leche.

"Con la adhesión de España a la Comunidad Económica Europea, ratificada el 12 de junio de 1985, se somete a la potestad normativa de las instituciones comunitarias que desde ese momento reconoce $y$ asume.

Las normas promulgadas por las instituciones comunitarias reciben diversas denominaciones, reglamentos, directivas, decisiones, recomendaciones y dictámenes, todas ellas sometidas a los Tratados Fundacionales (articulo 189 Tratado de la Comunidad Económica Europea, articulo 161 del Tratado C.E.E.A. y artículos 14,15 y 33 Tratado C.E.C.A.). El Consejo representa los intereses de los Estados miembros y la Comisión de los intereses propios de la Comunidad, compartiendo uno y otra el poder legislativo y el poder ejecutivo. Por su parte el Tribunal de Justicia ha establecido los principios generales del efecto directo y de la primacía del derecho comunitario, el primero comporta de un lado que las normas comunitarias no necesitan ser reflejadas por normas de derecho interno, sino que son directamente aplicables desde su publicación en el Diario Oficial de las Comunidades, y de otra que las normas comunitarias son fuente inmediata de 
derechos y obligaciones para aquéllos a quienes conciernen, sean Estados miembros o particulares, que sean partes de relaciones juridicas derivadas del Derecho Comunitario. Son pues sujetos del derecho comunitario tanto los Estados miembros como sus ciudadanos. Ahora bien, la sutileza de la distinción entre los conceptos de efecto y aplicabilidad directa, permite en la práctica utilizarlos como sinónimos. $Y$ en cualquier caso gozan de este efecto directo las normas comunitarias que sean "self-executing", es decir, completas y juridicamente perfectas. Los Reglamentos comunitarios que no participan de esa aptitud carecen de efecto directo, cuando necesitan de apoyos complementarios de desarrollo para precisar el alcance de los derechos particulares a los que aquéllos se refieren. Esta carencia obedece al mismo principio que niega con carácter general efecto directo a las directivas ante su naturaleza asimilable a las Leyes de Base necesitadas de un desarrollo posterior por los Estados miembros. En tal sentido las normas sobre competencia y procedimiento de los recursos judiciales destinados a garantizar los derechos que se derivan para los particulares del efecto directo del derecho comunitario, corresponden al Ordenamiento nacional, sin que sus modalidades puedan ser menos favorables que las de otros recursos similares de naturaleza interna (Sentencia de dieciséis de diciembre de mil novecientos setenta y seis) y corresponde al mismo Ordenamiento interno, cuando sea necesario para la aplicación de un reglamento comunitario, la adaptación de ciertos servicios públicos del Estado miembro, pudiendo éste incurrir en responsabilidad por inactividad causante del incumplimiento (articulo 169 del Tratado y Sentencia de cinco de mayo de mil novecientos setenta). Refuerza este criterio el que el nacimiento de los derechos de los particulares derivados de una norma comunitaria, no se condicionan a la adopción de las medidas de desarrollo por el Estado miembro (Sentencia Leonesio de dieciséis de mayo de mil novecientos setenta y uno) con lo cual se concede el efecto directo en cuanto la disposición comunitaria favorezca el derecho de los particulares.

Los reglamentos y directivas comunitarias tienen valor de leyes marco cuya primacía sobre las normas internas y efecto directo en su caso no podrán ser discutidos, desde el momento de la adhesión a los tratados fundacionales. Las normas anteriores que se opongan al Derecho comunitario deberán entenderse derogadas y las posteriores contrarias, habrán de reputarse inconstitucionales por incompetencia -artículos 93 y 96.1 de la Constitución Española- pero no será exigible que el juez ordinario plantee la cuestión de inconstitucionalidad (articulo 163 de la Constitución Española) para dejar inaplicada la norma estatal, porque está vinculado por la Jurisprudencia del Tribunal de 
Justicia que tiene establecido el principio "pro communitate". Finalmente las normas y actos de desarrollo serán competencia del Legislativo o Ejecutivo del Estado, cuestión deferida al derecho interno de los paises miembros a cuyo poder judicial compete la aplicación directa de las normas comunitarias y el planteamiento en su caso del recurso de prejudicialidad ante el Tribunal de Justicia de las Comunidades, en orden a la uniformidad del derecho comunitario.

Debe admitirse que los Reglamentos comunitarios 1079 y $1822 / 1977$ que implantaron la tasa de corresponsabilidad, una vez producida la adhesión de España a las Comunidades Europeas, quedaron integrados en nuestro Ordenamiento interno. Fue necesario no obstante recurrir a un sistema de acomodación encomendado primero al Real Decreto 2750/1956 de 5 de diciembre, regulador de la liquidación, recaudación y control de la nueva tasa y después a la Orden de 7 de diciembre de 1957, ahora impugnada, que además de aprobar el modelo 451 de autoliquidación y detallar el modo de cumplimentarlo, incorpora también en su disposición transitoria, las declaraciones e ingresos pendientes, respecto de las operaciones realizadas en el período comprendido entre la entrada en vigor del Real Decreto 2750/1956, en 18 de enero de 1957 y la fecha de entrada en vigor de la propia Orden, prevista para el 1 de enero de 1955. En esta situación, conviene distinguir entre el nacimiento de la obligación tributaria, cuyos elementos esenciales configura, tanto el Reglamento comunitario, como el Real Decreto 2750/1986 y el momento en que se termina de instrumentar el procedimiento recaudatorio, intervalo en el que la obligación tributaria ya nacida sólo está pendiente de cumplimiento y sujeta a una moratoria, sin verdadero efecto extintivo. No creemos por ello que la disposición transitoria al referirse a tasas anteriores a la fecha de la orden, tenga auténtica calidad retroactiva. Es cierto que la disposición transitoria, tal como está concebida, no hubiera sido necesaria de haber asumido el Real Decreto 2750/1986 la confección y aprobación del modelo, de autoliquidación, pero en cualquier caso, los plazos de liquidación del Reglamento comunitario, que entró en vigor en la fecha del acta de adhesión (12 de junio de 1985) se hubieran tenido que distorsionar necesariamente ante la incorporación de un nuevo Estado miembro, integrado en la dinámica normativa comunitaria que no había interrumpido su curso para facilitar la coordinación de los dos Ordenamientos.

Ya hemos dicho que los reglamentos que necesitan de normas complementarias para precisar el alcance de los derechos de los particulares no tienen efecto directo, pero en nuestro supuesto, tanto los derechos como las obligaciones de los particulares en lo que a la tasa de corresponsabilidad se refiere están ya perfectamente configurados 
a través del hecho imponible, sujeto pasivo, devengo y demás elementos esenciales del tributo en el propio Reglamento comunitario, de modo que una vez seleccionado el órgano gestor por el Real Decreto $2750 / 1986$ la exigibilidad material de las tasas devengadas desde ese momento, sólo dependía de la modalidad recaudatoria adoptada por la Orden mediante la aprobación del modelo 451, que no afectaba al nacimiento de la obligación tributaria aunque aplazara el momento de su cumplimiento. Pero es que además aunque se asimilara este $R e-$ glamento a las directivas por su efecto indirecto, el artículo $395 \mathrm{del}$ Tratado de Adhesión de 1985 preceptúa que los nuevos Estados miembros pondrán en vigor las medidas necesarias para cumplir desde el momento de la adhesión las disposiciones de las normas indirectas, con lo cual habria que situar la obligatoriedad de la tasa incluso en fecha anterior a la entrada en vigor del Real Decreto 2750/1986, conclusión más gravosa para los particulares que la derivada de la aplicación de la Orden. Desde esta perspectiva, si la obligación de retener no nace de la Orden, sino que viene directamente vinculada al Reglamento comunitario, a través del Tratado de Adhesión, la Disposición Transitoria no restringe el derecho de aquéllos cuando aplaza las declaraciones e ingresos de unas tasas devengadas, retenidas o que hubieran debido retenerse, para hacerlas coincidir con las declaraciones-liquidaciones que se efectúen con arreglo a la Orden posterior, ampliando un plazo en definitiva más ventajoso a los intereses de aquélla sobre quien pesa la obligación de retener. No será preciso reiterar que obedeciendo el fundamento de la liquidación a disposiciones anteriores a la Orden Ministerial cuestionada, la disposición transitoria no implica retroactividad sino simple aplazamiento en la liquidación e ingreso de la tasa de corresponsabilidad, no susceptible de infringir los principios que la Confederación recurrente considera conculcados, criterio imprescindiblemente utilizado cuando se aplica el efecto indirecto para ser consecuente con la primacía del derecho comunitario, que al quedar asumido por un Estado miembro y necesitar una adaptación al Ordenamiento interno, exige un plazo, cuya duración no excluye la aplicación de la norma comunitaria, desde el momento anterior de la adhesión.

Las mismas razones expuestas sirven para rechazar que la Disposición Transitoria es contraria a derecho porque establece por Orden Ministerial el periodo de devengo de una obligación tributaria. Es, en efecto, el Reglamento comunitario el que establece el devengo, que no se prolonga en el tiempo sino que se produce y agota en el momento de la entrega del producto al comprador, surgiendo desde entonces la obligación de retener, aunque el ingreso quede luego aplazado, determinación de índole recaudatoria, no afectada por el 
principio de reserva de ley. En cuanto a la supuesta frustración de expectativas legítimas, carece en este caso de la eficacia enervatoria pretendida, pues estando en función de una legitimidad desestimada con arreglo a lo expuesto con anterioridad no hay base para aceptarla. Por el contrario, la expectativa legitima que se desprendería de una normativa donde se establece una tasa, es la de que habrá de satisfacer su importe una vez devengada y éste y el resto de los elementos esenciales del tributo aparecían ya configurados en los Reglamentos comunitarios y en el Real Decreto $2750 / 1956$. "

(Sentencia de 24 de abril de 1990. Ar. 2747. A. LLORENTE CALAMA.)

2. Retroactividad de las normas. Seguridad Social de los trabajadores del mar. Los Reglamentos pueden ser retroactivos siempre que los controles de la legalidad no sean qebrantados , o, lo es lo mismo, siempre que el Reglamento traiga su retroactividad de una disposición con rango de Ley que lo habilite para ello. El limite de la retroactividad in pejus no es general, si no que está referido únicamente a las leyes "ex post facto" sancionadora o restrictivas de derechos individuales.

"La Sentencia de primera instancia, dictada por la Sala de lo Contencioso-Administrativo correspondiente, por la que estimándose parcialmente el recurso contencioso-administrativo interpuesto por I.C., S.A. contra la Resolución de la Dirección General del Régimen Económico y Jurídico de la Seguridad Social de 31 de octubre de 1984 , en el particular de dicha resolución que confirmó el recargo por mora contenido en las actas de la Inspección del Trabajo, particular y recargo que anuló, por ilegal, desestimando el recurso en el resto, por ajustarse a Derecho, en lo demás, los actos administrativos impugnados, es objeto de sendos recursos de apelación, formulados, uno de ellos por la entidad actora, y el otro por la Administración, alegándose fundamentalmente por la primera, no ser procedentes las liquidaciones contenidas en el acto recurrido, al no poderse atribuir efectos retroactivos a las Resoluciones de la Dirección Provincial de Trabajo y Seguridad Social de Las Palmas, publicadas en el B.O. de la Provincia, en 10 de abril de 1982 y 24 de marzo de 1983, de que las liquidaciones traen causa, por no concurrir en dichas resoluciones los presupuestos legales necesarios para que su retroactividad sea procedente, y por la segunda, que el recargo por mora reputado ilegal en la sentencia recurrida, debe ser declarado procedente, puesto que no habiendo la entidad interesada presentado los documentos de cotización dentro del plazo reglamentario, se la requirió mediante acta de la Inspección para que abonase las cuotas debidas. 
Los problemas que ambos recursos plantean, han sido abordados y resueltos por múltiples Sentencias de esta Sala, de las que pueden servir de exponente, las de 18 de abril, 5 y 10 de octubre de 1985, 3 de enero, 3 de febrero, 21 de marzo, 28 de abril, 30 de mayo y 5 y 14 de diciembre de 1959 y 9 de febrero de 1990, a las que hay que atenerse por el principio de unidad de doctrina -y razones de seguridad jurídica- al no concurrir circunstancias diversas que aconsejen otra distinta; asi cabe decir con ellas, respecto a la retroactividad invocada, que frente a la tesis de que al haberse publicado las bases de cotización en 10 de abril de 1952 y 24 de marzo de 1983, su aplicación a meses anteriores implica darles un antijurídico efecto retroactivo, ha de tenerse en cuenta, que ya desde la Ley 116/1969, de 30 de diciembre, las bases de cotización de los trabajadores portuarios, hay que calcularlas sobre la base de los valores medios de remuneración percibida en el año precedente, siguiendo para su determinación un procedimiento legalmente establecido, lo que supone haya de realizarse dentro del mismo año en que se cotiza, y que, por tanto, la fijación administrativa de aquéllas, sean siempre posterior al inicio del año en que deban aplicarse, lo que no autoriza a afirmar que con ello se incurra en una ilegal retroactividad, ya que las resoluciones administrativas de la Delegación Provincial de Trabajo y Seguridad Social de Las Palmas, se limitan a concretar numéricamente las bases que vienen predeterminadas por la Ley y en razón de cuyo elemento definidos (valores medios de remuneración percibida en el año precedente) alcanzan fuerza de obligar aquellas resoluciones, de modo que a través de éstas, lo que se hace exclusivamente es delimitar la cuantía exacta de una obligación, cuyos elementos esenciales están definidos directamente por la Ley.

Igualmente, con relación a la cuestión planteada por el representante legal de la Administración, es de afirmar, conforme a la doctrina de la sentencias anteriormente indicadas, que consta en el expediente que la empresa actora ingresó lo que consideraba debido en concepto de cuotas a la Seguridad Social, de acuerdo con la solicitud que al efecto le dirigió la Organización de Trabajos Portuarios, para unos concretos periodos, sin que posteriormente se formulara respecto de éstos por referido Organismo reparo alguno, no constando por el contrario, que las liquidaciones complementarias hubiesen sido notificadas en forma a la empresa, con anterioridad al levantamiento de las actas de la Inspección que las contenía ya con el recargo de demora, faltando pues el requisito de previo requerimiento y fijación de plazos para el pago, requisito inexcusable para la procedencia de la mora respecto de tan referidas liquidaciones complementarias.

(Sentencia de 25 de Junio de 1990. Ar. 4685. J. Moreno Moreno.) 


\title{
II.- ORGANIZACION ADMINISTRATIVA.
}

\begin{abstract}
1. Administración Local. Aprobación de estructura orgánica y funcionamiento del personal al servicio de la Corporación municipal. El acuerdo municipal que al efecto se tome no puede estimarse como disposición reglamentaria sino como una norma organizativa, por lo cual no es exigible la información pública indicada en el art. 109 de la Ley de Régimen Local de 24-6-55.
\end{abstract}

"La nulidad de Pleno Derecho del Acuerdo impugnado en este proceso aducida por la Asociación recurrente, apelante en esta instancia, por no haber el Ayuntamiento de Valencia tramitado el expediente de conformidad con lo dispuesto en el articulo 109 de la Ley de Régimen Local de 24-6-55 vigente en la fecha en que se adoptó el Acuerdo de 19-7-84 e incidir, por consiguiente, la causa prevista en el articulo 47-I-c) de la Ley de Procedimiento Administrativo, debe ser analizada por este Tribunal, ya que el no haberse invocado en el escrito de la demanda y si en la de conclusiones no excluye que se examine su procedencia o inadmisión dada la naturaleza de este motivo que pudiera estimarse de oficio y de la que pudiera derivar la nulidad de los extremos puntuales relativos a la clasificación como Jefaturas de Sección el Laboratorio y Farmacia Municipales, el Centro Sanitario Municipal y cuatro Casas de Socorro objeto del suplico de la demanda, en la que se pidió su clasificación como Jefatura de Servicio excepto el Centro Sanitario para el que se postuló se declarara como Unidad Administrativa de Administración Especial, equivalente a una Jefatura de Distrito y Viceinterventor.

El Acuerdo Municipal recurrido comprende la aprobación de la Estructura Orgánica y Funcional, Organigramas, y Manual de Funciones y Competencias del Personal al Servicio de la Corporación Municipal de Valencia, regulando y clasificando unos servicios ya existentes incardinando en esa clasificación distintas unidades orgánicas en base a unos criterios técnicos acomodados al Decreto de 1-2-82 y Orden Ministerial de 25-2-82, de conformidad con la potestad organizativa que le corresponde con efectos técnico-competenciales que en orden a la consideración como Secciones adscritas a los servicios de Sanidad Asistencial e Instituto Municipal de la Salud comprendidos en la Subárea de Sanidad, Area de Promoción Ciudadana y Bienestar Social, objeto de la pretensión no puede estimarse como disposición reglamentaria con efectos trascendentes a toda la comunidad, sino una norma organizativa basada en criterios técnicos y objetivos funcionales de adscripción y clasificación de unas unidades orgánicas de 
asistencia sanitaria y consiguiente integración en ellas de los funcionarios y personal que los atienden, por lo cual no es exigible la información pública indicada en el articulo 109 de la Ley de Régimen Local citada; estando acorde con el Decreto de 1-2-82 sobre retribuciones de los funcionarios de la Administración Local y Orden de 25-2-82, en cuyo articulo $4^{\circ}$ se dispone que las Entidades Locales y clasificarán sus puestos de trabajo según la población del Municipio tal como se establece en el Anexo del Real Decreto de 1-2-82; conformando la atribución de la condición de secciones a los indicados centros sanitarios, según lo dispuesto en el Anexo VI de esa Orden, atendiendo a su funcionalidad como puesto de mando que depende directamente de una Jefatura de Servicio ante la que es responsable y cuya competencia comprende dentro del sector o grupo de funciones en que se divide el Servicio y siguiendo las directrices que éste le marque, funciones de estudio, asesoramiento, y propuesta de carácter superior, y la directa realización de actividades para las que capacita especificamente un título superior circunstancias que concurren en las meritadas Secciones, que no pueden ser estimadas como "Servicios" al no integrarse en ellas como mínimo dos Secciones que requieren a la vez la de tres negociados, según se contempla en el anexo citado; no siendo pertinente estimar como Jefatura de Servicio a efectos organizativos y de organigrama el que una dependencia municipal se residencie en un inmueble de propiedad municipal ni que en ella se preste uno de los incluidos como mínimos en la Ley para que merezcan la consideración de "Servicio", ya que es preciso diferenciar el concepto y término servicio como función, del que dimana de su clasificación a efectos organizativos, en los que dentro de una determinada actividad administrativa, en este caso la sanitaria, no puede existir ningún centro independiente que rompa con la necesaria integración jerárquica, orgánica y funcional que requiera el servicio.

La pretensión de la recurrente de que se anulen las clasificaciones indicadas del Laboratorio y Farmacia Municipales, Centro Sanitario, y Casas de Socorro como Jefaturas de Sección no puede motivarse en la nulidad de Pleno Derecho invocada del articulo 47-I-c) de la Ley de Procedimiento Administrativo, al no concurrir en este disposición la exigencia de la información pública dados los meros efectos internos y organizativos que inciden en la misma, procediendo rechazar ese motivo de la pretensión, así como el acertadamente resuelto por el Tribunal de instancia en relación con los derechos de los funcionarios, ya que, sin perjuicio de haberse cumplido con lo dispuesto en el Real Decreto y Orden meritados en el apartado anterior, la categoría de los adscritos a un servicio municipal, de entender que deba atribuirsele una en particular, no puede condicionar la consideración y 
clasificación que a efectos de la prestación de un servicio se contemple como pertinente; debiendo a este respecto hacer constar que en el expediente administrativo se informó por la Jefatura de personal, la Comisión Informativa de Gobierno, y la Secretaria General, de cuyos dictámenes no se deduce que por la nueva estructura orgánica aprobada se vulnerarán los derechos de los funcionarios adscritos a los servicios indicados, ni aquéllos han alegado esa circunstancia; no pudiendo pretener la clasificación de una sección de la Administración Especial como Jefatura de Servicio con la finalidad de que se estimen como servicios prestados en una unidad superior a la de sección a efectos de futuros ascensos en la categoría personal del funcionario, por impedirselo así la exigencia de una ordenación objetiva de los servicios del Ayuntamiento que vienen condicionados por criterios de legalidad, eficacia y coherencia organizativa."

(Sentencia de 4 de abril de 1990. Ar. 3625. J. GARCIA ESTARTUS.)

2. Impugnación de acuerdos de las Corporaciones locales al amparo de los artículos 65 y 66 de la LBRL. Errónea interpretación municipal en virtud de la cual el Ayuntamiento, supervalorando el concepto de autonomía, ha omitido solicitar un informe preceptivo $y$ semivinculante que corresponde emitir a la comunidad Autónoma.

"En la presente apelación se cuestiona la validez jurídica de la sentencia de la Sala de lo contencioso-administrativo de la Audiencia Territorial de Palma de Mallorca de 21 de marzo de 1958 que estimó el recurso 231/86 interpuesto por la Comunidad Autónoma de las Islas Baleares Contra los acuerdos señalados con los números 7, 8, 9, 12 y 13 del acta Correspondiente a la la sesión Celebrada por la Comisión del Gobierno del Ayuntamiento de Manacor (Mallorca), de 30 de abril de 1986, así como contra el Acuerdo de la meritada Comisión de 18 de junio de 1986, que declaró inadmisible y subsidiariamente desestimó el requerimiento de la expresada Comunidad autónoma del Ayuntamiento citado para la anulación de los citados acuerdos.

El requerimiento de que se acaba de hablar se hizo invocando el articulo 65 de la nueva Ley básica estatal de régimen local que instrumenta una vía administrativa previa que parece que haya que entenderlo como un recurso de reposición especial potestativo previo al contencioso-administrativo, recurso administrativo que se fundamenta en la defensa del Ordenamiento jurídico pero que no es, sin embargo, un recurso "en interés de la ley" porque si el acto llegara a ser anulado lo seria con todas sus consecuencias, esto es, afectando a las situaciones individuales creadas por el acto revocado. 
En autos figura, en efecto, el emplazamiento hecho a los afectados por los acuerdos impugnados, acuerdos que versan sobre lo siguiente:

Acuerdo 7: Otorgamiento de licencia de apertura de un local dedicado a salón de máquinas, de juegos electrónicos y servicios de cafetería.

Acuerdo 8: Licencia de apertura de un local dedicado a la venta mayor de productos alimenticios.

Acuerdo 9: Licencia de apertura y funcionamiento de un local dedicado a la fábrica de pan y bollería.

Acuerdo 12: Licencia de apertura de un local destinado a bar.

Acuerdo 13: Licencia de apertura de un local dedicado a almacén y venta al por mayor de vinos y licores.

Dichas actividades se consideran incluidas en el ámbito de las sometidas al Reglamento ( estatal) de actividades molestas, insalubres, nocivas y peligrosas de 30 de noviembre de 1961.

Se considera también por la Comunidad balear que han incumplido los artículos 2,7 y 31 del citado Reglamento y 4 y 8 de la Instrucción de 15 de marzo de 1963, por faltar el informe de la Comisión interinsular de saneamiento, órgano regional al que corresponde ahora las competencias de gestión atribuidas a órgano estatal en aquellas normas.

Se ha planteado en primera instancia, y se reitera ante esta Sala, el problema de si el supuesto de hecho que sirve de base a este proceso -omisión del informe previsto en el Reglamento de actividades molestas, insalubres, nocivas o peligrosas, que en este caso habria de emitir un órgano regional- encaja en el articulo 65 (infracción del ordenamiento jurídico) o en el articulo 66 (infracción del ordenamiento competencial), ambos de la nueva Ley básica (que no de bases) estatal de régimen local. Problema que, en opinión del Ayuntamiento, conlleva consecuencias procesales como seria la necesidad en el caso del articulo 66, de tener que recurrir en el plazo de quince dias que aquí aparece sobrepasado, y de que, en el caso del articulo 65, se aplicaría el régimen general del contencioso-administrativo, por aplicación del articulo 63.1. Aunque también dice el Ayuntamiento que hay que contraponer el supuesto del articulo 63.1 del contemplado en los artículos 65 y 66 . Las alegaciones municipales, en todo caso, resultan oscuras, lo que es perfectamente comprensible ya que tampoco los preceptos que invoca son un dechado de claridad. Por su parte, el Letrado de la Comunidad autónoma ha silenciado el problema.

Pues bien, esta Sala no ve contraposición entre el articulo 63 y los artículos 65 y 66 . Salvo -eso si- que el articulo 63 contiene una 
ampliación de la legitimación, o quizá una aclaración sobre este problema, y los artículos 65 y 66 contienen previsiones procesales, o si se refiere, relativas a la andadura procesal, a los trámites a seguir.

Por otra parte, mientras el articulo 65 parece contemplar el supuesto general de infracción del ordenamiento jurídico, el 66 se refiere a un supuesto especifico el de infracción del ordenamiento competencial (por menoscabo, por interferencia o por exceso). $Y$ en ambos casos contempla relaciones entre el Estado o las Regiones, de una parte y las Corporaciones locales de otra. Lo que ocurre es que luego la diferenciación entre el supuesto de hecho del articulo 65 y el de 66 no es tan nítida, porque la frase "considere, en el ámbito de su respectiva competencia" es perfectamente oscura. Probablemente ha querido decirse que la Administración del Estado en todo el territorio nacional, y las Administraciones regionales en su respectivo territorio y respecto de las Corporaciones locales que quedan bajo su jurisdicción, pueden impugnar cualquier acto local que, según su parecer, sea contrario al ordenamiento jurídico.

Aqui ciertamente podría entenderse -y habría entonces que dar la razón al Ayuntamiento- que estamos ante un problema de competencia, y no porque el Ayuntamiento haya ejercido una competencia que no tiene, sino porque ha impedido que la Comunidad autónoma ejerza una competencia que tiene, competencia que, como luego se dirá no es puramente consultiva.

Pero si bien se mira no es eso lo que ha ocurrido, sino algo más simple: una errónea interpretación municipal en virtud de la cual el Ayuntamiento -supervalorando el concepto de autonomía pero sin propósito de menoscabar o interferir competencias ajenas, y sin excederse tampoco de las propias- ha omitido solicitar un informe preceptivo y semivinculante que corresponde emitir a la Comunidad balear, la cual "considerando, en el ámbito de su competencia" que dicha omisión constituye infracción del ordenamiento jurídico ha usado de la vía del articulo 65 .

Adviértase también que si no queremos convertir en inconsecuente el articulo 66 -que podría llevarnos al absurdo de que un problema de competencia que puede suponer nulidad de pleno derecho conforme al articulo 47 de la Ley de Procedimiento Administrativo deviniera inatacable por el transcurso del fugaz plazo de quince días que marcahay que admitir que ese articulo no impide el que pueda utilizarse la vía general con interposición previa de recurso de reposición (por lo demás, subsanable si se hubiese omitido). Con lo que también el recurso tendria que admitirse.

Esta Sala es consciente de que con esta interpretación se está relativizando la aparente compartimentación de los artículos 65 y 66 . 
Pero es que, en realidad, lo que late en el fondo de esta regulación es facilitar un control -las cosas hay que aceptarlas en su desnuda realidad-por parte del Estado y de las Comunidades Autónomas de la actuación de las Corporaciones Locales. Porque conferimiento de autonomía no supone creación de ruedas locales que giran a su aire sin conexión alguna con los restantes elementos del sistema. Un Estado, sea unitario, autonómico o federal, es una totalidad organizada cuyos distintos elementos actúan conforme a reglas de coherencia e inteligibilidad y cuyo funcionamiento es preciso asegurar mediante los oportunos mecanismos de dirección, de alimentación y también de frenado. Mecanismos que, por otra parte, no tienen necesariamente que ser accionados desde el centro. Mecanismos cuya existencia en nuestro ordenamiento es innegable como lo prueba, por ejemplo, el que se hable en ese articulo 65 de "requerimiento" de anulación de un acto formal elaborado por la Corporación local, y que implica el reconocimiento de una evidente supremacía de unas Administraciones sobre otras.

Procede ahora -salvado ya el obstáculo procesal analizado en el fundamento anterior- entrar en el fondo del asunto. $Y$ en relación con ello ha quedado ya anticipado que el informe aqui omitido es algo más que puro ejercicio de una función consultiva. Porque aquí se trata de un informe semivinculante, $y$ en este tipo de informes, como en general en los vinculantes, lo que hay es una potestad decisoria enmascarada. Porque lo que ocurre es que por razones no siempre explicables se ha optado por mantener formalmente en manos de una organización la decisión que, sin embargo, materialmente ha sido transferida o se retiene por otra. De manera que el contenido de la decisión se elabora por el órgano informante y el que aparece decidiendo cara al público se limita a dar forma o vestidura a aquella decisión. Otras veces lo que hay es ejercicio de competencias concurrentes con decisiones sucesivas que se manifiestan en un acto único. Es el caso del articulo 39 de la Ley de Procedimiento Administrativo y también del supuesto que nos ocupa.

Si aquí se tratara de la simple omisión de un informe preceptivo podria jugar la doctrina reciente del Tribunal Supremo en relación con la omisión del informe del Consejo de Estado, según la cual la imposibilidad de convalidación que para estos casos prevé el artículo 53.5 juega en el ámbito de las relaciones interadministrativas y no impide a los Tribunales entrar a conocer el fondo del asunto -cfr. por todas las Sentencias de la Sala de revisión del Tribunal Supremo de 29 de Octubre de 1987-. Pero aquí -repetimos- bajo la vestidura de informe se oculta algo más: el ejercicio de una competencia decisoria que afecta al medio ambiente, materia en la que tiene competencia básica 
el Estado y normativa y de gestión las Comunidades Autónomas -art. 249. 1.23 y 148. 1.9 de la Constitución-. Por tanto, no cabe invocar -como hace el Ayuntamiento- invasión de la autonomía local. Y el artículo 12 del Estatuto balear -que goza de la presunción de constitucionalidad- confirma esta interpretación. "

(Sentencia de 12 de marzo de 1990. Ar. 3404. F. GONZALEZ NAVARRO.)

\section{III.- HACIENDAS LOCALES}

1. País Vasco: régimen económico financiero especial en los términos de la Ley de Concierto Económico. Actos Tributarios de las Corporaciones Locales. Impugnación en vía económico-administrativa improcedente. Anulación del precepto que así lo dispone por la Norma Foral General Tributaria del Territorio Histórico de Vizcaya.

"Para resolver la cuestión planteada en el presente recurso de apelación por el Ayuntamiento de Sestao, hay que partir de los artículos 108 y 113 de la Ley de Bases de Régimen Local de 2 de abril de 1986. Tanto la Ley de Bases en los artículos citados como el Texto Refundido que la desarrolla, disponen que en materia de imposición de tributos o aprobación y modificación de Ordenanzas, procede directamente el recurso contencioso-administrativo, mientras que contra los actos de las Corporaciones Locales sobre aplicación y efectividad de tributos locales, podrá interponerse ante el órgano que lo dictó el correspondiente recurso de reposición previo al contencioso-administrativo. Con este nuevo sistema de recursos, queda suprimida la fiscalización, por los Tribunales Económicos-Administrativos, respecto de las disposiciones y actos mencionados anteriormente, como reconoce la sentencia apelada que gráficamente razona, con cita de los preceptos antes invocados, que ello significa "la desaparición de los Tribunales Económico-Administrativos de la estructura administrativa-tributaria en la que estaban enclavados" en lo que se refiere a exacciones locales, puesto que dichos Tribunales conservan sus competencias respecto a los Impuestos estatales.

La aplicación de las normas citadas a las distintas Comunidades viene dada por las Disposiciones Adicionales de la Ley de Bases. Por lo que respecta el caso que nos ocupa, la Disposición Adicional Segunda, 6 de la Ley de Bases establece que "Ios territorios históricos del Pais Vasco continuarán conservando su régimen especial en materia municipal en lo que afecta al régimen económico-financiero en 
los términos de la Ley del Concierto Económico, sin que ello pueda significar un nivel de autonomía de las Corporaciones Locales vascas inferior al que tengan las demás Corporaciones Locales... ". El reenvío que se hace en esta Disposición Adicional, significa la aplicación al caso de lo dispuesto en el articulo 45 de la Ley de 13 de mayo de 1981, mediante la que se aprueba dicho Concierto Económico, según cuyo articulo 45 -párrafo 2- las facultades de tutela financiera que en cada momento desempeñaba el Estado en materia de imposición y ordenación de los tributos (propios de las Corporaciones Locales) corresponderá a las respectivas Diputaciones Forales, sin que ello pueda significar, en modo alguno, un nivel de autonomia de las Corporaciones Locales Vascas inferior al que tengan las de régimen común. Como razona el Ayuntamiento apelante al argumentar sobre este punto, lo que ha hecho el legislador ha sido sustituir al Estado por las Diputaciones Forales, en cuanto a la competencia que aquél tenía en materia de imposición y ordenación de tributos, pero sin conceder a las Diputaciones más derechos que los que tenía el Estado a quien sustituye.

Siendo verdaderamente importante la recopilación y examen de los antecedentes históricos que la sentencia apelada realiza, lo cierto es que hay que partir, para la resolución del presente recurso, de la situación existente en el Estado español en el momento en el que se aprueba la Normal Foral impugnada, es decir, en el año 1986, puesto que la misma evolución histórica recogida en las numerosísimas disposiciones de distinto rango que la sentencia menciona, ponen de manifiesto que la evolución de la competencia y funciones atribuidas a los Tribunales de esa misma naturaleza en el resto del Estado, por to que, no existe motivo alguno para que en el momento presente se prescinda de ese paralelismo y se siga manteniendo, para la fiscalización de los acuerdos de las Corporaciones Locales del País Vasco, una fiscalización que ha sido suprimida para el resto de los Ayuntamientos del Estado (y no hay por qué examinar en este sentencia la situación existente en la Comunidad Foral de Navarra, por no ser la enjuiciada en este recurso). Pero es que, además, no es válido el argumento de que la Ley de Bases de Régimen Local y los preceptos del Texto Refundido que la desarrolla, sean de mera aplicación supletoria en el País Vasco, porque los razonamientos en los que se basa la sentencia apelada, no permiten llegar a tal conclusión. Se invoca para ello el artículo 133 de la Constitución que nada resuelve, puesto que se limita a reconocer a las Comunidades Autónomas competencia para exigir tributos, y esta competencia no es objeto de discusión. Lo mismo puede decirse de la invocación de la Disposición Adicional Primera de la Constitución, que se limita a "amparar 
y respetar Los derechos históricos de los territorios forales, añadiendo que su actualización general del régimen foral se llevará a cabo, en su caso, en el marco de la Constitución y de los Estatutos de Autonomía", ya que la discusión parlamentaria pone de manifiesto que el origen de la mencionada discusión se produjo respecto del principio de soberanía (independencia originaria de los territorios forales y soberanía, y forma de actualización de los derechos históricos, o mediante una Ley paccionada o mediante la Constitución y los Estatutos de Autonomia), y, en el presente caso no nos hallamos ante uno de tales "derechos históricos" que afecte a la libertad e independencia del pueblo Vasco, sino ante la posibilidad de que los acuerdos de sus Ayuntamientos en materia económico-fiscal, puedan ser o no fiscalizados por órganos de la propia Administración, o deban de seguir el régimen de los restantes Municipios del Estado, lo que no puede elevarse al rango de "derecho histórico" de los mencionados en la Disposición Adicional Primera de la Constitución. Lo mismo puede decirse del Real Decreto Legislativo de 12 de diciembre de 1980, que en su Disposición Adicional única se limita a decir que, "de conformidad con lo dispuesto en las Disposiciones Adicionales Primera y Segunda de la Ley de 22 de septiembre de 1980, en los territorios forales las normas de este Real Decreto se aplicarán de conformidad con los preceptuado en los respectivos Estatutos de Autonomía o Convenio Económico en su caso", estableciendo a su vez la Disposición Adicional Primera de la Ley Orgánica de Financiación de las Comunidades Autónomas de 22 de septiembre de 1980 -que es la citada por el Real Decreto Legislativo de 1980 antes transcrito- que "el sistema foral tradicional de concierto económico se aplicará en la Comunidad Autónoma del País Vasco, de acuerdo con lo establecido en el correspondiente Estatuto de Autonomía". Ninguno de los preceptos que se examinan permite llegar a la conclusión a la que llega la sentencia apelada, es decir, a la aplicación supletoria de la Ley de Bases de Régimen Local y de su Texto Refundido, que es el motivo que en la mencionada sentencia sirve para desestimar el recurso interpuesto por el Ayuntamiento de Sestao.

Es cierto que la Ley Orgánica de Financiación de las Comunidades Autónomas de 22 de septiembre de 1980, en su articulo 20, mantiene las reclamaciones económico-administrativas, pero lo hace para “los actos dictados por las respectivas Administraciones en materia tributaria, tanto respecto de cuestiones de hecho como de derecho: a) cuando se trate de tributos de las Comunidades Autónomas, a sus propios órganos económico-administrativos; b) cuando se trate de tributos cedidos a los órganos económico-administrativos del Estado", lo que no 
resuelve la cuestión planteada, ya que no nos hallamos ante un debate sobre si existe o no la vía económico-administrativa, sino ante otra cuestión diferente que es si subsiste dicha reclamación contra los actos o disposiciones de los Ayuntamientos en materia de imposición municipal, no comunitaria, y la Ley, como hemos visto en el precepto transcrito, se refiere a los tributos "propios de la Comunidad".

Lo mismo ocurre si acudimos a lo dispuesto en la Ley Orgánica de 18 de diciembre de 1979, que aprueba el Estatuto de Autonomía del País Vasco, ya que el precepto aplicable será el número 1 del articulo 41, Según el cual "las relaciones de orden tributario entre el Estado y el País Vasco vendrán reguladas mediante el Sistema foral tradicional de Concierto Económico o Convenio" lo que se desarrolla en los apartados siguientes, de entre los cuales interesa a este recurso el apartado a) del párrafo 2, Según el cual el contenido del régimen económico del Concierto respetará y se acomodará a los siguientes principios: a) "Las Instituciones competentes de los Territorios Históricos podrán mantener, establecer y regular, dentro de su Territorio, el régimen tributario, atendiendo a la estructura general impositiva del Estado, a las normas que para la coordinación, armonización fiscal y colaboración con el Estado se contengan en el propio concierto y a las que dicte el Parlamento Vasco para idénticas finalidades dentro de la Comunidad Autónoma... ". Pues bien, tampoco este precepto, por si solo resuelve la cuestión, ya que, en primer lugar, no parece posible entender incluido dentro de lo denominado "estructura general impositiva" el régimen de reclamaciones contra los actos de gestión o aprobación de Ordenanzas, pero, en segundo lugar, y si ello se entendiera posible, lo que el Estatuto dice es que se atenderá al dictar las normas, a las dictadas "para la coordinación, armonización fiscal y colaboración con el Estado se contengan el el Concierto y a las que el Parlamento dicte para el mismo fin". Como anteriormente hemos razonado, el Concierto Económico, aprobado por Ley de 13 de mayo de 1981, dispone en su articulo 45-2, en primer lugar, que la tutela financiera que desempeñaba el Estado, es asumida por las Diputaciones Forales, y en segundo lugar, que esta asunción de competencias no significa en modo alguno un nivel de autonomía de las Corporaciones Locales -del País Vasco- inferior al que tengan las de régimen común, con lo que, después del examen de las numerosas disposiciones citadas por la sentencia apelada, nos hallamos en el mismo punto del que partimos.

Debe de partirse, para resolver la cuestión planteada, de lo dispuesto en el articulo 137 de la Constitución, según el cual los municipios "gozan de autonomía para la gestión de sus respectivos intereses", lo que ratifica el articulo 140 de la propia Constitución al decir 
que ésta "garantiza la autonomia de los Municipios, que gozaran de personalidad jurídica plena". Pues bien, esta autonomia proclamada constitucionalmente, es incompatible con una intervención de la Administración mediante la cual se apruebe o rechace un acuerdo de una Corporación Local mediante el que se apruebe un presupuesto, imponga un tributo o se apruebe o modifique una Ordenanza fiscal. Es indiferente a estos efectos, que ese acto de la Administración se dicte por una Corporación o por un órgano de la Administración que se denomine Tribunal, pero que es la propia Administración la que lo establece, regula su composición, dicta normas de procedimiento y determina sus competencias, $y$ es indiferente también que la actividad de dicho órgano fiscalizador se ponga en marcha bien de oficio bien a instancia de parte, puesto que la esencia de la tutela es que un órgano de la Administración, no superior jerárquico de otro, pueda o bien autorizar, o bien anular, o bien sustituirlo, y esto y no otra cosa ocurre cuando los acuerdos de una Corporación Local aprobando un presupuesto, o aprobando una Ordenanza, pueden ser no ya sólo suspendidos, sino anulados en todo o en parte por otro órgano de la Administración, con lo que la autonomía constitucionalmente declarada queda no ya limitada o disminuida, sino prácticamente anulada. Cabe dentro de lo posible que los acuerdos municipales no reúnan todos los requisitos de forma o de fondo, para ser eficaces; pero ello deberá ser puesto de manifiesto solicitando la actividad de un poder independiente de la Administración, como es el judicial, con objeto de que la autonomia municipal sea cierta, real y verdadera. Por las mismas razones expuestas, tampoco procede admitir la intervención de los Tribunales Económico-Administrativos para conocer en lo referente a materias de aplicación y efectividad de tributos, pudiendo agregarse a lo ya dicho que supondría el establecimiento de un régimen de desigualdad al someter a los Municipios del País Vasco a un régimen ya desaparecido para el resto de los municipios del Estado, sin que las peculiaridades existentes desde luego, en el Territorio Histórico, autoricen tal desigualdad, que va en perjuicio de un derecho constitucionalmente reconocido, como es el de la autonomía municipal.

Como el párrafo 2 del articulo 161 de la Norma Foral impugnada atenta contra la autonomía municipal, debe ser declarado contrario a derecho, y como tal anulado, lo que produce como consecuencia la estimación del recurso de apelación interpuesto por el Ayuntamiento de Sestao, revocando la sentencia apelada que había llegado a la conclusión contraria.

(Sentencia de 3 de abril de 1990. Ar. 2553. J. L. MARTIN HERRERO.) 


\title{
IV.- EMPLEO PUBLICO
}

\begin{abstract}
1. Relaciones de puestos de trabajo. La indicación expresa de las tareas que corresponden al puesto, el contenido funcional del mismo, son características esenciales que no siempre son fáciles deducibles de la denominación, titulación, etc. De la misma manera, la descomposición y explicación de las claves numéricas que anteceden a cada puesto debe constar en el expediente.
\end{abstract}

El punto de partida de la sentencia apelada se refiere a la exigencia de que consten las características esenciales de los puestos de trabajo relacionados, cuestión básica que enfrenta a la actora con la Junta demandada y que proyecta su influencia sobre casi todos los extremos discutidos. La parte apelante estima que en cada puesto de trabajo incluido en las relaciones se dan datos suficientes para configurar sus características esenciales mientras que la parte actora estima lo contrario y la sentencia recurrida la sigue en especial en los "casos singularizados cuyas funciones (se sobrentiende las que se desempeñan en cada puesto) no coincidan las propias de los cuerpos o escalas".

La demandante considera que las indicaciones consignadas en las relaciones incumplen totalmente lo previsto en el articulo 32.1 de la Ley $5 / 85$ porque la descomposición y explicación de las claves numéricas que anteceden a cada puesto debió constar en el expediente y al no hacerse así faltan datos sobre las características esenciales de cada puesto. Esta objeción que en principio era un reproche formal realizado en la sentencia cobra de nuevo importancia al examinar por vía de ejemplo lo ocurrido con el tratamiento dado a las jefaturas de $\mathrm{Ne}$ gociado (asp. 5 y $6^{\circ}$ del hecho tercero de la demanda), puestos que pueden ser cubiertos por varios Cuerpos y en los que es imposible discernir el contenido funcional sin descripción de las tareas que les están encomendadas -(págs. 25 y 31 de las relaciones).

Las alegaciones presentadas en esta instancia por la parte apelante examinan sucesivamente los preceptos de la Ley Regional 5/85 que la sentencia da como infringidos por el Decreto 43/87 -artículo 32 , en relación con el 94 b) artículo 95.3), artículo 22.2 y por último el articulo 54.3 de la citada Ley- $y$ rechaza una a una las infracciones apreciadas en los fundamentos de la misma por entender en general que las relaciones, una -vez aclaradas las cifras y letras que identifican el puesto por las explicaciones dadas en la contestación, no revelan infracción frontal alguna, o bien en caso de que pudieran encontrarse imprecisiones que produjeran perplejidad se trataria de 
meros temores más que de violaciones comprobadas. Soslaya sin embargo el examen de los puntos de la demanda antes citados aps. $5^{\circ}$ y $6^{\circ}$ del hecho tercero) y en particular pasa por alto la relación de 14 puestos de Jefes de negociado que pueden ser cubiertos en personal de tres cuerpos distintos (págs. 25 y 31 de las relaciones).

Las observaciones anteriores pueden resumirse diciendo que la indicación expresa de las tareas que corresponden al puesto (tarea es la palabra usada en el articulo 94.6 de la Ley 5/85) o sea el contenido funcional del mismo (Expresión del articulo 3.1 del Decreto 43/87) son características esenciales que no siempre son fácilmente deducibles de la denominación, titulación etc. junto a las claves cuya significación no explicadas ni en el texto del Decreto ni al comienzo de las relaciones como se hace en alguna de las relaciones de puestos de trabajo aportada por la demanda (véanse los folios 66 y 67 de Relación de puestos de la Seguridad Social).

Ciertamente la Sentencia de esta Sala de 20 de julio de 1989 afirmó que no se infringía el articulo 32.1. de la Ley citada cuando se trata de plazas o puestos de letrados, apreciación de difícil traslación a los puestos a que nos hemos referido en los fundamentos $3^{\circ}$ y $4^{\circ}$ de esta sentencia.

Admitido que las tareas especificas o contenido funcional son no sólo características relevantes de los puestos sino además dificilmente determinables en muchos casos y de imposible adivinación en alguno, esta conclusión repercute en la decisión de los otros problemas relativos al artículo 95.3 ( fundamento cuarto de la sentencia apelada) y el artículo 22.2 de la repetida Ley 5/85.

Queda por último la infracción del artículo 54.3 de la Ley de la Función Pública de Castilla la Mancha, que introdujo la sentencia apelada en sus fundamentos a pesar de que la parte actora no había aducido este motivo en la demanda. Respecto a este extremo la apelante acusa en primer lugar la incongruencia en que incurre la sentencia apelada al introducir una causa nueva de anulación sin utilizar la vía del artículo 43.2 de la Ley de la Jurisdicción, pero en esta instancia ese aspecto procesal debe entenderse superado una vez que el principio de previa audiencia sobre cualquier cuestión litigiosa no propuesta por las partes queda respetado ya que la parte apelante ha tratado extensamente la incidencia del articulo 54.3 de la Ley $5 / 85$ de la Comunidad, ofreciendo una interpretación distinta a la dada por numerosas sentencias de la Sala de lo Contencioso-Administrativo de la Audiencia Territorial de Albacete que concluyen la ilegalidad del "sistema del Decreto 43/87, al admitir éste la superposición de los niveles correspondientes a los diferentes grupos". Esta posición ha sido consagrada por la Sentencia de esta Sala de 20 de julio de 
1989 que confirmó la anulación del Decreto impugnado el mismo que aquí se impugna."

(Sentencia de 19 de abril de 1990. Ar. 3554. A. BURON BARBA.)

\section{V.- ACTOS ADMINISTRATIVOS}

1. Notificaciones. No es suficiente acreditamiento la fotocopia que documenta el "anverso" de un tarjeta-acuse de recibo postal, sin que incluya el contenido del "reverso" donde habían de constar los datos precisos para tener como efectuada la notificación en forma.

"Además de los fundamentos jurídicos que sirven a la sentencia ahora combatida para declarar la nulidad de actuaciones, que, se aceptan con las matizaciones que después se dirán y se dan por unidos a la presente; se ha de considerar que, los demandantes en el recurso contencioso-administrativo poseen dominio completo tanto sobre su derecho sustantivo como sobre los derechos procesales implícitos en el mismo, en el sentido de que son libres de ejercitarlos o no, asi como en relación a la forma alternativa de su ejercicio; no pudiendo ser obligado, en contra de su voluntad, a actuar en el proceso una determinada pretensión pudiendo el mismo libremente articularla, en caso de ser varias, por el orden de prelación alternativa que a su derecho convenga, debiendo el Organo jurisdiccional ante el que se actúen, juzgar dentro del limite de las pretensiones formuladas por las partes -artículo 43 de la Ley reguladora de esta jurisdicción-, sin olvidar el orden y naturaleza de las mismas, de tal suerte que ha de comenzar por el conocimiento y resolución de las articuladas con carácter principal y, sólo cuando éstas sean desestimadas seguir con las actuadas con carácter subsidiario, de forma que, estimadas las primeras no ha lugar a entrar a conocer y resolver sobre las subsidiarias ulteriores; por ello, la primera y más genuina manifestación de dicho principio dispositivo del ejercicio de las pretensiones procesales estriba, pues, en que sin demandante ni pretensión no hay proceso -nemo iudex sine actore-, mas no sólo la voluntad del demandante determina el proceso, sino que delimita en principio su contenido en cuanto que en el proceso contencioso-administrativo no es posible la "reconvención" por parte de la demandada, el cual si bien puede formular sus contra-pretensiones, éstas han de ir encaminadas a mantener su oposición, total o parcial, a las pretensiones actuadas de contrario en el recurso contencioso-administrativo, siendo ambas partes libres de efectuar las alegaciones que a sus respectivos intereses convengan 
para fundamentar el recurso y la oposición; no habiéndose de confundir dicha disponibilidad procesal para el ejercicio de las pretensiones y contraprestaciones respectivas antes aludidas -al que ninguna de ellas puede ser obligado-, con la posibilidad de que el Tribunal, al ir a dictar sentencia, estime que la cuestión sometida en su conocimiento pudiera no haber sido apreciada debidamente por las partes, por existir en apariencia otros motivos susceptibles de fundar el recurso o la oposición, en cuyo caso puede aquél someterlos a la consideración de las partes, en la forma, por el plazo y con el alcance que determina el párrafo 2, del articulo 43 , anteriormente citado. Por ello fue absolutamente congruente la sentencia ahora apelada cuando acogiendo la pretensión principal actuada en la demanda no entró a conocer de la subsidiaria que la parte actora alternativamente articula.

La demanda de la primera instancia fundaba su pretensión en orden a la nulidad de actuaciones del expediente administrativo sustancialmente en el hecho de que, no había tenido conocimiento del expediente administrativo donde la Orden Ministerial de revocación de la autorización cuestionada se habia producido, lo que le había producido indefensión en la vía administrativa, al privarle de la preceptiva audiencia como parte interesada, así como de la oportunidad de alegaciones y pruebas, con vulneración de la normativa jurídica procedimental de carácter esencial, originándole con ello el impago de las subvenciones a que tenia derecho, el cierre del Colegio Privado del que era titular, quedándose sin ingresos de ninguna clase e incluso sin posibilidad de acogerse a los remedios extraordinarios establecidos por el Gobierno para los denominados "centros en crisis"; mientras que la representación de la Administración demandada alega que, a los folios $20,19,17$ y 15 del expediente administrativo consta acreditado el hecho de haberse comunicado al interesado la existencia del mismo, no habiéndose producido la indefensión alegada de contrario, lo que implica la no procedencia de la declaración de nulidad de actuaciones y reposición de las que la sentencia apelada efectúa. Pues a tal respecto se ha de tener en cuenta que, en el expediente remitido por la Administración a los efectos de lo establecido en los artículos 61 y 67 de la Ley reguladora, de esta jurisdicción no consta que las comunicaciones que la Administración dice haber enviado al interesado, hubieren llegado o hubiere tenido conocimiento de ellas el interesado, así como tampoco que se le hubieran notificado en legal forma los actos contenidos en las mismas, pues, no es suficiente acreditamiento la fotocopia obrante al folio 18 del expediente, la cual documenta sólo el "anverso" de una tarjeta-acuse de recibo postal, sin que incluya el contenido del "reverso" donde habrian de constar los datos precisos para tener como efectuada la notificación 
en forma, por mediación de la Oficina de Correos correspondiente, cuya carga de la prueba incumbía a la Administración que alega el hecho de haber realizado la notificación en forma y el rechazo de su admisión por el notificador; $y$, si ello no fuera bastante para determinar la falta de notificación acusada por el señor M.G., es de observar como acordado por la Sala de instancia, recabar de la Administración que alegaba dicho hecho positivo, certificación acreditativa justificativa del rehuse por el interesado del certificado postal, aquélla omitió dicho acreditamiento al no cumplir lo que en tal sentido y para mejor proveer la Sala le interesaba, todo lo cual lleva a la conclusión a través de un razonamiento lógico fundado, de que al interesado no se le dió ocasión para efectuar alegaciones ni proponer o aportar pruebas en el expediente en defensa de sus derechos, produciéndose la Orden Ministerial revocatoria de la autorización "inaudita parte" produciéndose con ello una manifiesta indefensión para el interesado, con clara infracción de las normas contenidas en los artículos 23-b), 79-1, 91-1 y concordantes de la Ley de Procedimiento Administrativo, de obligada observancia al contener requisitos esenciales para la producción del acto impugnado.

El fundamento jurídico determinante de la nulidad y retroacción de actuaciones que la sentencia recurrida declara, se encuentra en la normativa contenida en el articulo 48.2, de la Ley de Procedimiento Administrativo, al tratarse la omisión de la audiencia del interesado, con la consiguiente privación para el mismo de hacer alegaciones y proponer o aportar pruebas en defensa de sus derechos o intereses legítimos, un defecto de forma en el expediente que indudablemente dió lugar a la indefensión para aquél; no siendo también de aplicación la normativa jurídica contenida en el articulo 47.1.c) de la citada Ley, como la sentencia apelada argumenta, ya que la Orden Ministerial combatida no fue producida "prescindiendo total y absolutamente del procedimiento legalmente establecido para ello", sino que sólo se omitieron algunos trámites indispensables que dieron lugar a la indefensión aludida del interesado".

(Sentencia de 5 de abril de 1990. Ar. 2767. MANTINEZ SANJUAN.)

2. Licencia urbanística y licencia de apertura. El otorgamiento de la licencia de obras sin la de apertura integra un funcionamiento anormal de la Administración que puede generar una responsabilidad patrimonial.

"Es ya tradicional en nuestro Derecho la distinción entre la licencia urbanística y la licencia de apertura. Mientras la primera contempla y 
autoriza, en lo que ahora importa, la construcción de un edificio o su reforma, la segunda proyecta el control preventivo sobre la actividad a desarrollar en aquél.

Esta dualidad de conceptos, con regulación en cuerpos normativos formalmente diferenciados, implica una quiebra en la aspiración de universalidad característica del urbanismo que pretende abarcar todos los aspectos jurídicos de la relación del hombre con el medio en que vive, quiebra esta que ha recibido apoyo de la Constitución que al regular sobre la base del principio de la competencia el nuevo reparto territorial del poder que representan las Comunidades Autónomas diferencia el urbanismo y la ordenación del territorio, por un lado, y la protección del medio ambiente, por otro -arts. $148,1,3^{\mathrm{a}}$ y $9^{\mathrm{a}} \mathrm{y}$ $149,1,23^{\mathrm{a}}$.

$Y$ esta diferenciación formal de la licencia urbanística y la apertura ha dado lugar a un determinado encadenamiento temporal de ambas: la licencia de apertura ha de obtenerse con anterioridad, o por lo menos simultáneamente, a la licencia urbanística para evitar el gasto innecesario de una construcción en la que no va a resultar posible la actividad que se pretende. Es claro que las obras no son un fin en si mismas sino el medio para el desarrollo de una actividad, de suerte que de no resultar esta viable no seria razonable e iría contra el principio de la buena fe autorizar la realización de aquéllas -Sentencias de 8 de mayo y 25 de octubre de 1989.

Así lo advierte el art. 22,3 del Reglamento de Servicios, que prescribe que, cuando con arreglo al proyecto presentado, la edificación de un inmueble se destine especificamente a establecimiento de características determinadas, no se concederá el permiso de obras sin el otorgamiento de la licencia de apertura, si fuera procedente.

Por consecuencia de lo expuesto resulta claro que el otorgamiento de la licencia de obras sin la de apertura integra un funcionamiento anormal de la Administración que puede generar una responsabilidad patrimonial -Sentencia de 25 de julio de 1986- con arreglo a lo dispuesto en los arts. 106,2 de la Constitución, 40 de la Ley de Régimen Jurídico de la Administración del Estado, 121 de la Ley de Expropiación forzosa y 54 de la Ley Reguladora de las Bases del Régimen Local 7-1985, de 2 de abril.

$Y$ este es justamente el caso litigioso, como con acierto pone de relieve la sentencia recurrida, pues no se aprecia por parte del en su dia demandante una conducta con trascendencia bastante para interrumpir el nexo de casualidad de sus perjuicios con el otorgamiento de la licencia de obras sin la previa de apertura, posteriormente denegada: 
A) por un lado resulta que tal demandante al solicitar la licencia de obras y con la misma fecha -folio 14 del expediente administrativo- formuló la declaración previa a la solicitud de apertura.

B) Por otro, si bien la licencia de obras no implica el otorgamiento tácito de la de apertura si constituye una autorización de las obras que por tanto puede realizar ya el administrado al que no puede exigírsele la previsión concreta de determinados efectos aditivos.

(Sentencia de 15 de junio de 1990. Ar. 4829. J. DELGADO BARRIO.)

\section{VI.- CONTRATOS}

1. Pago por compra de varias parcelas del polígono de Bufalvent al Instituto Catalán del Suelo. Toda compensación de deudas exige ineludiblemente un acto administrativo firme que reconozca y liquide los créditos correspondientes. La exigibilidad de una deuda no deviene de la ejecutibidad del acto administrativo, sino de la certeza de la deuda tributaria por haber adquirido firmeza la resolución administrativa.

"Para disipar, ante todo, cualquier duda que pudiera plantearse al respecto, no es inútil hacer ver que, evidentemente cuando la legislación aplicable al caso permite la compensación de las "deudas tributarias", no puede entenderse en el sentido de que exija que sólo procede aquélla cuando los créditos que se enfrenten tengan idéntica naturaleza, porque la heterogeneidad de los pretendidos compensar no desvirtúa la verdadera esencia y específica teleología de este modo extintivo de las obligaciones que no son otras que la realidad de que existan dos sujetos, privados o públicos, intervinientes en las mismas, que sean reciprocamente acreedores y deudores los unos de los otros, según exige el articulo 1195 del Código Civil, cuya aplicación supletoria a casos como el presente es incuestionable.

Esto sentado, para desestimar la pretensión de apelación que se deduce, con alegaciones que constituyen improcedente insistencia en las que, formuladas en primera instancia, se rebatieron con acierto en la sentencia cuya revocación se postula, bastaría con aludir al modo como el Ayuntamiento apelante declaró la compensación de la deuda que había contraido con el Instituto Catalán del Suelo con la tributaria que éste, a su vez, contrajo en favor de aquél, porque, si el artículo 1256 del Código Civil, expresamente prohibe que el cumplimiento de los contratos quede al arbitrio de uno solo de los contratantes, por la 
misma razón -al menos- ha de entenderse prohibido que pueda extinguirse una obligación por esa decisión unilateral, como ocurría en esta ocasión y oportunamente denuncia el órgano autonómico apelado, toda vez que ya recordábamos en nuestra Sentencia de 23 de diciembre de 1988 que, "a tenor del art. 65.3 del Reglamento General de Recaudación toda compensación exige ineludiblemente un acto administrativo firme, recaido en procedimiento con audiencia de los interesados, que reconozca y liquide los créditos correspondientes", y es indudable en este caso -como en el que fue resuelto por la citada sentencia no se siguió "dicho procedimiento previo como cauce necesario para llegar a la compensación".

En este sentido, no puede alegarse, en relación con el requisito de la firmeza del acto administrativo del que resulte una de las deudas objeto de compensación -que, por supuesto, no puede confundirse con la del acto administrativo que ponga fin al procedimiento por el que se declare la misma-, que exigir ese carácter firme supondría desconocer el principio de legalidad y el de ejecutividad de los actos de la Administración que proclama el articulo 116 de la Ley de Procedimiento Administrativo, de lo que la parte apelante deduce la intrascendencia de la circunstancia de que el Instituto apelado tuviera recurrido ante el Tribunal Económico-Administrativo la resolución de la que resulta la deuda objeto de compensación, porque no es aquí lo esencial, propiamente, la firmeza del acto, sino la exigibilidad de los créditos compensables que su firmeza produce en la medida en que la propia sentencia que anteriormente citábamos, igualmente declaró que, tanto las normas especificas de carácter tributario como las del Código Civil, supletoriamente aplicables, "exigen, en todo caso, que las cantidades llamadas a compensar sean liquidas y exigibles y estas condiciones no resultan acreditadas" -ni ahora lo están en el caso que nos ocupa "por un reconocimiento en el caso que nos ocupa"por un reconocimiento expreso de las partes implicadas en la posible compensación ni por una decisión administrativa de carácter firme".

Después de cuanto queda razonado, poco hace falta explicar sobre la irrelevancia que tienen las alegaciones del propio apelante, referidas a que el Instituto Catalán del Suelo no probó la falta de firmeza de la deuda que aquél hacia objeto de la compensación, y a que ésta se encontraba también autorizada por el artículo 109 de la Ley Reguladora de las Bases de Régimen Local, pues, en cuanto a la primera, era la contraria firmeza la que había de ser probada por quien la venia invocando como efectivo presupuesto de la compensación que declaraba, según resulta del artículo 1214 del Código Civil, con carácter general, y muy específicamente del 114.1 de la Ley General Tributaria -precisamente invocado por el alegante-, porque, según 
este precepto, la referida certeza indudablemente "es el hecho constitutivo del derecho que se hacia valer", que, en concreto, era el de compensar, $y$, en relación con la segunda de dichas alegaciones, porque, aun siendo ello cierto, la propia norma exclusivamente autoriza la compensación "cuando se trate de deudas vencidas, liquidas y exigibles" -y por esto no la admitía la Sentencia de esta Sala de 30 de diciembre de 1986, con base en el apartado G. del punto cuarto del articulo 65 del Reglamento de Recaudación en el caso en que se trataba de una deuda que era objeto de aplazamiento-, y tal exigibilidad, como muy acertadamente explica la sentencia apelada (cuya integra confirmación es, por lo expuesto, procedente), "no deviene de la ejecutividad del acto administrativo, sino de la certeza de la deuda tributaria de modo que resulte incuestionable".

(Sentencia de 21 de mayo de 1990. Ar. 4429. REYES MONTERREAL.)

\section{El arrendamiento de instalaciones pertenecientes a las} Corporaciones Locales constituye una forma de gestión indirecta de los servicios de su competencia. Carácter administrativo de estos arrendamientos.

Insiste el hoy apelante en la naturaleza civil del contrato de que se trata, invocando al efecto la Sentencia de la que entonces era Sala $4^{\mathrm{a}}$ de este Tribunal Supremo de 13 de julio de 1987 que, con referencia a un supuesto análogo, deriva el carácter administrativo del contrato de la adscripción de la recaudación a un fin de interés público. $Y$, como quiera que aquí esa adscripción no está prevista, concluye el apelante que el contrato de que se trata es civil y que, por tanto, esta Sala carece de jurisdicción para conocer del asunto.

Sin embargo, y sin perjuicio de que la solución de la sentencia citada pueda tener validez en ciertos casos, parece que, con carácter general, debemos estar a lo que resulta de los artículos 113 y 135 a 140 del Reglamento de servicios de las Corporaciones locales, conforme a los cuales el arrendamiento de las instalaciones pertenecientes a las Corporaciones locales constituye una forma de gestión indirecta de los servicios de su competencia, siendo causa de resolución del contrato, además de las señaladas en el Reglamento de contratación de las Corporaciones locales, la demora en el pago, etc. , remisión esta que basta para probar el carácter administrativo de estos arrendamientos.

No cabe duda que aquí se han arrendado unas instalaciones -la plaza de toros- propiedad del Ayuntamiento, para la gestión de un servicio de competencia municipal. Y se da el caso, además de que conforme al artículo 25 de la Ley básica estatal de régimen local 
corresponde a los Municipios promover toda clase de actividades y prestar cuantos servicios públicos contribuyan a satisfacer las necesidades y aspiraciones de la comunidad vecinal, ejerciendo competencias, entre otras materias, en relación con actividades o instalaciones culturales y deportivas, ocupación del tiempo libre y turismo (letra me).

Es evidente, por tanto, que hay que admitir que el contrato de arrendamiento de la plaza de toros de Teruel, firmado en 10 de diciembre de 1985 en cuanto adscrito al desenvolvimiento de un aspecto de esa competencia municipal de ocupación del tiempo libre (sin que esto implique desconocer la faceta cultural y la deportiva del espectáculo taurino como tal) constituye un verdadero y propio contrato administrativo. Por donde hay que concluir que esta Sala, como la de la primera instancia, tienen jurisdicción y competencia para conocer de la cuestión aqui planteada".

(Sentencia de 29 de junio de 1950. Ar. 5756. F. GONZALEZ NAVARRO.)

\section{VII.- SANCIONES}

I. La doctrina general sobre el "non bis in idem" encuentra salvedades en los supuestos de supremacía especial. Deslinde de competencias respecto a la potestad disciplinaria en el ámbito de la Abogacía dada la posibilidad de que una conducta resulta subsumible tanto en los tipos trazados por el Estatuto general de la Abogacía como en los previstos en las leyes procesales y Ley Orgánica del Poder Judicial.

"La sanción impuesta al apelante como consecuencia del escrito forense de 22 de abril de 1983 plantea ante todo la cuestión del "non bis in idem".

Reiteradamente ha venido poniendo de relieve el Tribunal Constitucional que el non bis in idem es un principio general del Derecho que ha de estimarse recogido en nuestra Constitución en razón de su íntima conexión con el principio de legalidad y tipicidad -Sentencias 2-1981, de 30 de enero, 77-1983, de 3 de octubre, 159-1985, de 27 de noviembre, 66 y 94-1986, de 23 de mayo y 8 de julio, etc.- pero esta doctrina general puede encontrar salvedad en los supuestos de supremacía especial.

Ciertamente esta salvedad merecería algunas precisiones pero no son ahora necesarias dado que, independientemente de lo que pudiera derivar del inciso final del art. 448 de la Ley Orgánica del Poder 
Judicial, -aplicable aquí en cuanto tenga de más favorable-, dictada ya sentencia absolutoria en el proceso penal $n^{\circ} 65-1986$, procedente del Juzgado de Instrucción no 5 de Bilbao al que se acumuló el originado por el escrito en cuestión, sentencia aquella que ya ha ganado firmeza, la sanción impuesta por el Colegio vizcaíno no vulnera las exigencias del mencionado principio.

Siguiendo en el terreno del expediente 32-1983, será de señalar que la potestad disciplinaria en el ámbito de la Abogacía ha sido tradicionalmente atribuida en nuestro ordenamiento jurídico a los órganos jurisdiccionales y a los Colegios de Abogados, lo que plantea un problema de deslinde de competencias, dada la posibilidad de que una conducta resulta subsumible tanto en los tipos trazados por el Estatuto General de la Abogacía como en los previstos en las leyes procesales y Ley Orgánica del Poder Judicial.

Importa ante todo recordar que desde el punto de vista jurisdiccional tal potestad es un simple instrumento para hacer posible que el proceso cumpla su función en tanto que en el ámbito colegial las sanciones operan con la finalidad más general de contribuir al mantenimiento de un cierto nivel ético en los profesionales:

A) De estas ideas deriva ya un primer criterio delimitador: con carácter general la potestad disciplinaria corresponde a los Colegios -art. 5o. i) de la Ley de 2-1974, de 13 de febrero pero cuando la infracción se comete en el curso de un proceso aquella potestad resultará ser de titularidad jurisdiccional. En esta última línea, ya antes de la Ley Orgánica -art. 451.1 la Ley de Enjuiciamiento Civil había establecido la competencia de los órganos jurisdiccionales para la corrección de las infracciones producidas en el curso de un proceso -art. 446 y en relación con el mismo, art. 258 de la Ley de Enjuiciamiento Criminal-.

B) El criterio que acaba de señalarse ha de ser matizado: a) dado que la potestad disciplinaria de los órganos jurisdiccionales en el terreno que se examina aspira meramente a garantizar el buen desarrollo del proceso hay que entender que las infracciones a sancionar por los jueces son de tono menor, lo que queda bien claro en la expresa dicción del art. 446 de la Ley de Enjuiciamiento Civil -se hubiesen propasado en la defensa oral-; b) justamente por ello las sanciones que pueden imponer los órganos jurisdiccionales tienen menor entidad que las que resultan viables a los Colegios: en este sentido resulta bien expresiva la comparación del texto del art. 109 del Estatuto General de la Abogacía con el del art. 449 de la Ley de Enjuiciamiento Civil y sobre todo, hoy, con el del art. 450.1 de la Ley Orgánica. 
Así las cosas, ha de entenderse que aunque la regla general, en el campo de las actuaciones procesales, en la competencia judicial, cuando la infracción trasciende del campo puramente procesal para afectar a niveles éticos de índole más general la competencia para la sanción deberá corresponder al Colegio aunque la infracción se haya cometido en el curso de un proceso.

Desde otro punto de vista, el Derecho Administrativo sancionador se caracteriza por la flexibilidad con que lleva a cabo la tipificación de las infracciones y el señalamiento de las sanciones correspondientes, especialmente en el ámbito de la supremacia especial -Sentencia del Tribunal Constitucional 219-89, de 21 de diciembre-. Esta flexibilidad no implica en modo alguno discrecionalidad. El carácter reglado de la potestad sancionadora -art. 25.1 de la Constitución-impide que la Administración pueda tener libertad para elegir soluciones distintas pero igualmente justas -indiferentes juridicamente-: no cabe pensar que dos sanciones diferentes puedan ser igualmente justas. La jurisprudencia de esta Sala viene insistiendo en este punto así, Sentencia de 23 de enero de 1989- poniendo de relieve que el principio de la proporcionalidad $o$, dicho de otra manera, los principios penales de individualización de la sanción para adaptarla a la gravedad del hecho y a la personalidad del autor, hacen de la determinación de la sanción una actividad reglada.

$Y$ el Derecho Administrativo sancionador conoce supuestos -y de ello es buena muestra la propia Ley Orgánica- en los que una infracción, según sus caracteristicas, pueda dar lugar a sanciones de mayor 0 menor entidad $y$ de competencia diferente según cual sea su gravedad.

En definitiva y dentro de las posibilidades que se aprecian -desde el delito hasta la infracción menor a sancionar por los órgahos jurisdiccionales, pasando por la figura de las infracciones de competencia colegial-, va de suyo, puesto que se trata de infracciones cometidas en el curso de un proceso, que serán conocidas ante todo por el órgano jurisdiccional ante el que se desarrolla aquél, que decidirá, en atención a las características del caso, en cuál de los supuestos mencionados son subsumibles los hechos.

En estos autos, los términos del escrito de 22 de abril de 1983, por un lado, no alteraban el desarrollo ordinario del proceso y por otro, aun sin ser constitutivos de delito -hay sentencia absolutoria-, afectaban muy gravemente a los deberes profesionales del Abogado -art. 48 del Estatuto-, lo que justificaba, en primer lugar, la decisión de la Sala de remitir testimonio del escrito al Colegio, y, en último término, la competencia de éste para imponer la sanción impugnada.

Finalmente y también en relación con el expediente 32-83 será de añadir: 
A) Ciertamente el procedimiento sancionador debe brindar en su seno y sin necesidad de llegar a la vía jurisdiccional plenas posibilidades de defensa que, en su caso, hagan innecesaria aquélla. Así lo viene poniendo de relieve la jurisprudencia tanto del Tribunal Constitucional -asi, Sentencia 29-1989, de 6 de febrero- como la del Tribunal Supremo -en este sentido, Sentencia de 20 de diciembre de 1989- aplicando los principios penales al campo de la potestad sancionadora de la Administración.

En el supuesto litigioso, resulta del expediente administrativo folio 69-que se formuló propuesta de resolución en la que con relato de los hechos e invocación de la norma aplicable se indicaba como sanción a imponer la de dos años de suspensión del ejercicio profesional, propuesta esta que fue conocida por el hoy apelante que formuló al respecto las alegaciones que entendió procedentes -folios 71 y siguientes y también 44 y siguientes-.

$Y$ con ello esta Sala entiende que hubo pleno conocimiento en la vía administrativa de la acusación formulada, lo que excluye la figura de la indefensión.

B) La acumulación de expedientes disciplinarios es una medida legalmente posible -art. 73 de la Ley de Procedimiento Administrativo-e incluso deseable pues la necesidad de individualizar la sanción, antes destacada, queda facilitada con el mejor conocimiento de la personalidad del expedientado: no se olvide el sentido fundamentalmente ético que tiene la potestad disciplinaria que ahora se examina y que aspira a lograr en este campo de la supremacía especial un determinado nivel de dignidad profesional en el ejercicio de la abogacia.

En último término tal acumulación no originó indefensión alguna.

Para el estudio de los demás expedientes disciplinarios importa recordar que como reiteradamente ha puesto de relieve el Tribunal Constitucional -así, Sentencia 47-1987, de 22 de abril- el derecho a un proceso justo incluye dentro de si el derecho a la defensa letrada -art. 24 de la Constitución- no sólo en el proceso penal sino en toda clase de juicios.

En este sentido ha de destacarse que la relación del cliente con su Abogado está basada en la confianza de suerte que desaparecida ésta debe cesar dicha relación sin que resulte admisible que posibles dificultades económicas impidan cambiar de letrado por la necesidad de pagar sus honorarios al anterior antes de que el nuevo Abogado asuma la defensa. No siempre el juego de los plazos admite dilaciones $y$ no resultaria razonable vincular al cliente con su primitivo letrado de suerte que éste continuara con la defensa de quien había perdido la confianza en él. 
Lo expuesto no significa sin más una inconstitucionalidad de la regulación contenida en el art. 33 del Estatuto General de la Abogacía que puede ser acomodada a la Constitución en los siguientes términos:

A) En cuanto a su párrafo primero será de indicar que la venta no implica el otorgamiento de una licencia o permiso del letrado anterior: el nuevo Abogado se dirige a su predecesor para que éste, ante todo, conozca la decisión del cliente $y$, en lo que ahora importa, pueda comunicar al letrado entrante sus honorarios a fin de que éste, "como regla de consideración", lleve a cabo las gestiones adecuadas para su pago.

B) En ningún caso las dificultades económicas para el pago de los honorarios podrán dar lugar a indefensión o a mantenimiento de la actuación de un Abogado en el que su cliente ha perdido la confianza. En este sentido ha de interpretarse el párrafo último del art. 33.1 del Estatuto.

C) Finalmente ha de entenderse posible, siempre que las circunstancias to impongan, que el nuevo letrado se haga cargo del asunto sin venia o autorización del Decano, dando cuenta a éste y al primitivo Abogado de Lo ocurrido lo antes posible. Es una manifestación más de la virtualidad de las circunstancias excepcionales para alterar las reglas ordinarias de procedimiento.

(Sentencia de 3 de abril de 1990. Ar. 3578. F.J. DELGADO BARRIO.)

\section{VIII. - RESPONSABILIDAD PATRIMONIAL.}

\section{Inundación por rotura de tubería de agua potable del abastecimiento municipal. Reclamación por aseguradora su- brogada en derechos del perjudicado. Inversión de la carga de la prueba. El Ayuntamiento resulta obligado a acreditar el error en la valoración efectuada y pagada por la compañía aseguradora.}

Realmente, la única cuestión a decidir en este recurso se limita a determinar si se hallan o no probados los importes de los daños sufridos por don Sixto L.G., propietario de un establecimiento textil, sito en la villa de Bilbao, en la esquina de las calles Bidebarrieta y Libertad, antes Ramiro de Maeztu, con ocasión de la rotura de una tubería de agua potable del abastecimiento municipal, acaecida el día 23 de agosto de 1984, que determinó la inundación del sótano del citado establecimiento, pues lo cierto es que no se discute, antes bien se reconoce, la rotura de la tubería, la inundación y la existencia real 
de daños como consecuencia de ésta; cierto que en una reclamación directa del perjudicado por el hecho de la inundación, era éste quien tenia que probar los daños y su importancia económica, pero éste no es el caso de autos, pues el propietario del establecimiento, titular de una póliza de seguro de daños con la entidad reclamante, instó de ésta el pago de la correspondiente indemnización, subrogándose la sociedad aseguradora en los derechos del asegurado, una vez pagada la cantidad de 658.581 pts. en que, pericialmente habían sido tasados los daños; es decir, existe en principio una base probatoria que no se puede desconocer, ya que lo reclamado por la sociedad aseguradora es la misma cantidad satisfecha por ella al asegurado, pues aunque aquélla reclamó al Excmo. Ayuntamiento de Bilbao los intereses correspondientes a esa cantidad desde la formulación de la reclamación en vía administrativa, tal pretensión fue declarada improcedente en instancia y la compañía reclamante se ha conformado con tal resolución; cierto que el art. 1214 del Código Civil carga sobre el que reclama la obligación de probar su pretensión, pero no lo es menos que las circunstancias del caso invertían la carga de la prueba, al venir obligado el Excmo. Ayuntamiento de Bilbao a acreditar el error en la valoración efectuada y pagada por la compañía y nada se dice de connivencias entre asegurador y asegurado, por cuanto ello, ni siquiera es alegado, y lo cierto es que nada se intentó, no ya en la fase jurisdiccional, donde compareció tarde la Corporación bilbaína, sino ni siquiera en la fase de expediente, donde ya constaba la peritación que sirve de base a la reclamación, y donde podría haber reclamado las facturas y precisiones que ahora estima en falta, máxime teniendo en cuenta que, conocedora del siniestro y de su responsabilidad, era obligación suya asumirla y cuantificarla y no tratar de escudarse en imprecisiones o errores que le correspondia eliminar en cumplimiento de la función administradora que le corresponde.

(Sentencia de 29 de mayo de 1990. Ar. 4619. JIMENEZ HERNANDEZ.)

\section{IX. - EXPROPIACION FORZOSA.}

I. Procede indemnizar los menoscabos que los particulares sufran en sus bienes $y$ derechos a consecuencia de una acción-expropiatoria, indemnización que debe alcanzar aquellos casos en que la acción expropiatoria, aún respetando el derecho de propiedad, produce una minusvaloración en parte de la finca no ocupada.

La jurisprudencia viene declarando con reiteración que hace a su doctrina complementaria del Ordenamiento jurídico, que procede 
indemnizar los deméritos o menoscabos que los particulares sufran en sus bienes y derechos a consecuencia de una acción expropiatoria, indemnización que debe alcanzar aquellos casos en que la acción expropiatoria, aun respetando el derecho de propiedad, produce una minusvaloración en parte de la finca no ocupada -Sentencia de 27 de diciembre de 1978- indemnización cuya procedencia viene siendo reconocida por este Tribunal, al margen de la regulada por el art. 46 de la Ley de Expropiación Forzosa, en el supuesto previsto en el apartado 23 del precitado Cuerpo Legal, distinguiendo la jurisprudencia la expropiación parcial que hace antieconómica la conservación del resto de la finca no expropiada, y la expropiación que disminuye el valor de la parte de finca no afectada por la expropiación, supuesto este último en el que no juega lo prescrito en los arts. 23 y 46 de la Ley de Expropiación Forzosa -Sentencia de 1-2-1978, ya que no puede confundirse la indemnización a que se refiere el art. 46 de la Ley de Expropiación Forzosa, que tiene como fundamento el resultado antieconómico para el propietario de la conservación del resto de la finca no expropiada, con la que procede para compensar el demérito que sufre la parte de finca no, expropiada, bien por su desvalorización, bien por la disminución de los beneficios que ésta rendia; indemnización que este Tribunal ha reconocido para compensar los perjuicios que suponen la elevación de la altura del suelo expropiado en relación con la rasante del resto del terreno -Sentencia de 1-4-63, y los que implica la pérdida de vistas de la finca no expropiada -Sentencia de 3-10-54, admitiendo la indemnización por la depreciación experimentada en las partes no expropiadas de una finca ocupada con motivo de la construcción de una autopista, entre otras, la Sentencia de 28 de mayo de 1980, reiterando la doctrina mantenida en las Sentencias de 18 de Marzo, 8 y 14 de abril de 1975; procediendo tal indemnización, aunque no se haya solicitado previamente la expropiación total de los bienes afectados por las obras que legitimen la expropiación de las fincas que se ocupan, toda vez que, como dicho queda, no se está en el caso de una finca que resulte antieconómica, su explotación, debido a la segregación del terreno que se ocupa.

La causa de los perjuicios cuya indemnización solicita la Sociedad Anónima "Química Farmacéutica Bayer, S.A." es la diferencia de altura de la calzada "Ronda de Langreo, que discurre en las inmediaciones de los edificios industriales propiedad de dicha Empresa y que en los planos que acompañan a la hoja de aprecio, formulada por la Entidad expropiada, se señalan con las letras A, B y C, altura, la que alcanzará la calzada de la Ronda de Langreo, que según el informe del señor Director Provincial del Ministerio de Industria y Energía en 
Asturias, obrante en la plieza de justiprecio, producirá que el edificio que en los mentados planos se identifica con la letra $A$, quede inutilizado como edificio industrial, dado que como consecuencia de la elevación de la calzada que constituye la Ronda de Langreo, gran parte del mismo quedaría sin luz natural y sin ventilación, produciéndose en él, dada su proximidad a la calzada, ruidos y vibraciones, lo cual asimismo puede predicarse del edificio identificado con la letra $B$, en los referidos planos, el cual quedará soterrado, encontrándose por debajo de la cota de la calzada, razón por la que no podrá destinarse a sus actuales servicios, dado el potencial riesgo de caída sobre el mismo de objetos que se puedan arrojar o caer desde la calzada, y otro tanto se puede decir del edificio referenciado con la letra $\mathrm{C}$. Consejutas las de los futuros perjuicios que se iban a ocasionar en la. Empresa Química Farmacéutica Bayer, S.A., con las obras de construcción de la Ronda de Langreo, que realizadas éstas se ven concretados en el detallado informe emitido en el recurso cuya apelación nos ocupa por el Arquitecto Superior don José Carlos F.F., designado previa insaculación para rendir el informe pericial solicitado como medio de prueba por la parte recurrente en instancia, informe en el que se precisa que la Ronda de Langreo pasa a una distancia del edificio que en los aludidos planos que se acompañan a la hoja de aprecio de la propiedad con la letra $A$, oscila entre 1 metro y 1,90 metros, superando el $40 \%$ de su altura, rebasando éste la segunda planta del edificio señalado con la letra $C$, en los mentados planos, y dejando muy abajo el edificio identificado con la letra $B$, edificios todos ellos que según se hace constar en el mencionado informe sufren un evidente deterioro, habida cuenta que las fachadas que daban a la antigua vía era el remate del borde edificado colindante a vias públicas de todo el Complejo Bayer, quedando los edificios de referencia materialmente pegados a la vía elevada o debajo de ella, perdiendo todo el valor y funcionalidad de sus fachadas, al ser perjudicadas $\mathrm{o}$ anuladas sus funciones arquitectónicas, como son la iluminación, el soleamiento, la privacidad, la salubridad, la capacidad estética y representativa y lo que es más importante la capacidad o posibilidad de acceso o salida directa a la calle; hechos que ponen de relieve las fotografías que acompañan el referido informe pericial, cuyas conclusiones son aceptadas por el Tribunal "a quo" en cuanto a la indemnización que procede conceder a la Empresa Química Farmacéutica Bayer, S.A. por la depreciación y daños que en los inmuebles de su propiedad ocasionaron las obras de construcción de la Ronda de Langreo, reconocimiento de indemnización plenamente asumible por esta Sala, al no quedar desvirtuados por las alegaciones de las partes los hechos que condujeron al mismo.

(Sentencia de 25 de junio de 1990. Ar. 4716. SANCHEZ ANDRADE Y SAL.) 
X. - BIENES.

1. Obras de construcción de un puerto deportivo sobre el litoral que incluye los terrenos ganados al mar. Delimitación de las competencias estatales y municipales. Corresponde a la Administración estatal la construcción del puerto en sí, y a la municipal los actos de edificación y uso del suelo en cuanto a los terrenos ganados al mar por las obras.

"La cuestión planteada en las presentes actuaciones se reduce a determinar si una vez otorgada por parte del Estado la pertinente concesión para la construcción de un Puerto Deportivo en el mar litoral, es o no necesario, para la realización de las obras de construcción del puerto en su primera fase de transformación física del lecho del mar litoral, la licencia municipal prevista en el articulo 178 y concordantes de la Ley del Suelo. La sentencia apelada, dictada por la Sala Jurisdiccional de la Audiencia Territorial de Palma de Mallorca, entiende, siguiendo la doctrina establecida por la sentencia de la antigua Sala $4^{\text {a }}$ de este Tribunal de 20 de febrero de 1984, que es indudable que el Estado (Ministerio de Obras Públicas y Urbanismo) es el competente para otorgar las concesiones demaniales o de obra o servicio público sobre bienes demaniales, en cuanto que el articulo 10.1 de la Ley de Costas -Ley 28/69 de 26 de abril- atribuye al referido Departamento Ministerial, "la gestión y tutela de los bienes de dominio público relacionados en los números 1 y 2 del articulo $1^{\circ}$ de la Ley, de los puertos y alumbrado marítimo, balizamiento, obras de defensa, saneamiento y ordenación de costas y playas"; como también el no 3 del mismo artículo le atribuye facultades para conceder -a través del procedimiento completado con los informes necesarios e incluso audiencias a particulares- la construcción dentro del mar, de muelles, embarcaderos, obras fijas, etc. con destino a servicio particular o público. Tal interpretación, continúa diciendo la sentencia apelada, se refuerza en el caso presente en el que se trata de obras de construcción de un puerto deportivo sobre el litoral que incluye los terrenos ganados al mar, regido por la Ley 55/69 de Puertos Deportivos y su Reglamento de 26 de septiembre de 1980, en cuyo ámbito es aún más sostenible la competencia exclusiva del Estado, ya que si bien la Ley de Costas atribuye a los Ayuntamientos "la gestión y tutela de los bienes de dominio público marítimo terrestre que determine el Gobierno a efectos del fomento de la pesca -articulo 11.4- y las de policía, moralidad, salubridad, etc. de las playas, salvamento y seguridad, e instalaciones no fijas y explotación de servicios ajenos -artículo 17-, ni la Ley de Puertos Deportivos ni su Reglamento, atribuyen competencia alguna a los 
Ayuntamientos, sin perjuicio de prever la posibilidad de que las Corporaciones puedan o deban ser concesionarios -artículo 17 y siguientes del Reglamento-, lo que, a juicio de la referida sentencia, refuerza la convicción jurídica de que la función de éstas en las concesiones se limita al informe preceptivo, puesto que la concesión, en lo referente a la construcción del puerto sobre el mar territorial y obras tendentes a ganar terrenos al mar, atribuye al titular de la concesión las habilitaciones necesarias para realizar las obras conforme al proyecto aprobado y bajo la dirección de la autoridad competente, por ser ello consecuencia de la naturaleza de la concesión que ha de ofrecer, por exigencia institucional, las facultades necesarias o suficientes para que el concesionario pueda realizar la obra o prestar el servicio.

La Comunidad de Propietarios del Édificio "Apartamentos de Mar", recurrente en primera instancia y ahora apelante, alega que la doctrina establecida en la referida Sentencia del Tribunal Supremo de 20 de febrero de 1984, invocada por la apelada para fundamentar su tesis, está en contradicción con reiterada jurisprudencia Sentencias de 2 de octubre de 1967, 24 de enero de 1974, 7 de julio de 1978, 30 de junio de 1979, 17 de marzo y 28 de junio de 1980, 25 de septiembre de 1981, 3 de diciembre de 1982, etc. - que declara que las obras en Dominio Público Marítimo exigen licencia municipal. Tal cuestión, contradicción o no entre aquella sentencia y éstas, dió lugar a la interposición de un recurso de revisión, al amparo del artículo 102. 1 b) de la Ley Jurisdiccional, que finalizó por Sentencia de la Sala Especial de Revisión de 4 de febrero de 1987, la cual declaró que la Sentencia recurrida - la de 20 de febrero de 1984- no contradice la doctrina establecida en las citadas sentencias, sino que partiendo de ella y de la unidad del término municipal, sin enclaves exentos, distingue en las concesiones sobre mar territorial dos fases: la inicial, para la cual se reconoce competencia exclusiva al Estado y la posterior, cuando los terrenos ganados al mar a consecuencia de las obras del puerto por accesión artificial, pasan a formar parte de la zona marítimo-terrestre, momento en que hay que observar la ordenación urbanística para los usos del suelo siendo entonces exigible la licencia municipal correspondiente, pues si se pretendiera que para verificar tales obras iniciales hubiera ya de obtener licencia urbanistica, la intervención de los Municipios no supondría una coordinación de competencias, sino una homologación sobre la concesión estatal que interferiría sobre un espacio que en este momento no es urbanístico y una superioridad de la actuación local sobre la estatal.

En relación, precisamente, con el puerto deportivo de invernada de Alicante, en el que recayo la tan reiterada Sentencia de 20 de febrero de 1984, se dictó también por la Sala $3^{\mathrm{a}}$ de este Tribunal la Sen- 
tencia de 18 de mayo de 1984 que dejó sin efecto la resolución del Consejo de Ministros, otorgante de la concesión, y ordenó la rehabilitación de la zona afectada por las obras a su estado primitivo, por no haberse solicitado la licencia municipal. Al estar esta segunda sentencia en contradicción con aquélla, se interpuso recurso de revisión, también al amparo del apartado b) del articulo 102.1 de la Ley Jurisdiccional, que finalizó por Sentencia de la Sala Especial de revisión de 19 de junio de 1987, la cual rescindió la Sentencia de 18 de mayo de 1984 por entender que la doctrina correcta era la contenida en la primera de las sentencias citada. En dicha sentencia de revisión se reitera que "corresponde la competencia, en cuanto a las concesiones y construcciones en el mar litoral al Ministerio de Obras Públicas, aunque sea preciso el informe favorable del Ayuntamiento interesado y haya de tenerse en cuenta en lo que respecta a la ubicación de un puerto deportivo, el planeamiento urbanístico aplicable a la zona costera pertinente; pero sin que la exigencia de este informe favorable del Ayuntamiento, ni la necesidad de no olvidar este planeamiento signifiquen que, una vez otorgada la concesión, previo el cumplimiento de estas formalidades, sea preciso para la realización de las obras de construcción del puerto en su primera fase de transformación física del lecho del mar territorial, la necesidad de la licencia municipal prevista en el artículo 178 y concertantes de la Ley del Suelo, porque una cosa es la concesión y otra muy distinta el otorgamiento de una licencia.

Como resumen de lo expuesto en las mencionadas Sentencias de la Sala $4^{\text {a }}$ del Tribunal Supremo de 20 de febrero de 1984 y de la Sala Especial de revisión de 4 de febrero y 19 de junio de 1987, la Sentencia de esta Sala de 25 de enero de 1988 declara que en la construcción de un puerto deportivo actúan con competencias propias la Administración estatal y la municipal, cada una en su espera privativa, correspondiendo a la primera intervenir en la construcción del puerto en si, y a la segunda en los actos de edificación y uso del suelo en cuanto a los terrenos ganados al mar por las obras, que por accesión artificial pasan a integrase en la zona marítimo-terrestre, momento en el que hay que observar la ordenación urbanística para los usos del suelo y edificación y es exigible la licencia municipal correspondiente conforme a los artículos 178, 179 y 180 de la Ley sobre Régimen del Suelo y Ordenación Urbana, Texto Refundido de 9 de abril de 1976. Por otra parte debe resaltarse que la Comunidad apelante interpuso, en su día, recurso contencioso-administrativo contra el Acuerdo del Consejo de Ministros de 13 de julio de 1981 por la que se otorgó a la Compañía Mercantil P.P., S.A. la concesión y explotación del puerto deportivo de invernada de Calviá, que dio lugar al recurso $n^{\circ} 306.620 / 82$. 
Las consideraciones anteriores determinan la imposibilidad de estimar el recurso, pues no siendo exigible, como hemos dicho, el otorgamiento de licencia municipal para la realización de las obras iniciales del puerto, deviene de todo punto innecesario un acuerdo municipal en tal sentido, toda vez que las mismas podian ser válidamente realizadas desde el momento en que se otorgó la pertinente concesión por parte de la Administración estatal competente, por lo que será en el recurso deducido contra esta resolución, y no en el inexistente, por innecesario, acuerdo municipal, al carecer esta última autoridad de competencia por razón de la materia para conocer de la pretensión ejercitada, donde deberán examinarse las cuestiones de fondo planteadas por la Comunidad de Propietarios recurrentes; procediendo, en consecuencia y de conformidad con lo dispuesto en los artículos 82 en relación con el 37.1 ambos de la Ley Jurisdiccional, confirmar la sentencia recurrida en cuanto declaró la inadmisibilidad del recurso; sin declaración especial sobre costas por no advertirse aquellas circunstancias de temeridad o mala fe procesales, a que se refiere el artículo 131 del texto legal últimamente citado.

(Sentencia de 4 de abril de 1990. Ar. 3583. ORO-PULIDO y LOPEZ.)

2. Conservación y rescate de los bienes de dominio público.

El ejercicio de la potestad defensora de los bienes de dominio público municipal por parte de la Corporación titular de los mismos no está a merced de un criterio de discrecionalidad por parte de ella. El status de estos bienes esta sometido a principios de derecho imperativo y necesario.

sLa primera gran contradicción en que incurre el tan repetido Ayuntamiento es haber empezado sus alegaciones cargando la tinta en una supuesta falta de legitimación del accionante, para terminar sosteniendo que, en realidad, la litis consiste en un conflicto de intereses personales entre el mismo y el denunciado, al que atribuye las obras origen del estrechamiento del camino de que se trata. Porque no cabe imaginar la tenencia de un interés directo en la promoción de un proceso mayor que cuando, como afirma el propio Ayuntamiento, lo que se ventila en autos como acabamos de decir, es un tipo de intereses de este tipo.

Además, no solo el actor tiene interés en que el camino quede expedito, recuperando su anterior anchura, sino en que se anule un acto administrativo, como el aquí recurrido, que, a su juicio, no es conforme a derecho, y que por recaer sobre un bien de dominio público municipal, puede ser revisado perfectamente, en el ámbito posesorio, por nuestros Tribunales de lo Contencioso. 
Pues bien, moviéndonos dentro de dicho ámbito, y frente a un acto de carácter netamente administrativo, lo primero que tenemos que decir es que el ejercicio de la potestad defensora de los bienes de dominio público municipal, por parte de la Corporación titular de los mismos, no está a merced de un criterio de discrecionalidad por parte de ella, pues si hay algo que esté sometido a principios de derecho imperativo y necesario, ese algo, de forma muy destacada, es el relacionado con el status de esta clase de bienes, algunos de ellos llamados incluso a desaparecer, si no se establecieran frenos a la codicia de los particulares.

Por otra parte, el propio acuerdo recurrido no apela a criterios de discrecionalidad, tan insistentemente mantenidos en el escrito de alegaciones del Ayuntamiento de Riosa, sino que se limita a emitir un pronunciamiento, estimatorio en parte del recurso de reposición interpuesto por el denunciante, en base a una interpretación subjetiva de los hechos denunciados, que son precisamente el centro del debate a resolver por nosotros.

Que no existe en esta materia el menor margen para la discrecionalidad administrativa lo evidencia la forma en que está redactado el art. 8 de la Ley del Patrimonio del Estado, texto articulado de 15 de abril de 1964, en el que se conjugan los verbos "poder" y "deber" simultáneamente. Viniendo el segundo de ellos a esclarecer el sentido en que el primero es empleado. En efecto, en dicho articulo, al declarase que "La Administración podrá recuperar por si la posesión indebidamente perdida sobre los bienes y derechos del Patrimonio... " emplea ese término no como sinónimo de poder optativo, potestativo o discrecional, sino como poder limitado en su ejercicio a un periodo determinado de tiempo (un año), puesto que ese "podrá" lo supedita a que se ejercite "...antes de que se cumpla un año, contando desde el día siguiente al de la usurpación". Ya que, a continuación, en el mismo artículo se ordena que "Transcurrido dicho plazo, la Administración deberá acudir a los Tribunales ordinarios ejercitando la acción correspondiente."

Plazo que no cuenta en la defensa de los bienes de dominio público, cualquiera que sea la Administración titular de los mismos, ya que, como es sabido, una de sus principales características es la de su imprescriptibilidad.

Con lo expuesto queda dicho todo en el terreno de los principios, en el supuesto que nos ocupa, pues si el poder de recuperar los bienes patrimoniales es un poder-deber, con mayor motivo ello debera ser así también cuando los bienes, como el camino en cuestión, es un bien de dominio público, al servicio de la comunidad vecinal principalmente. Motivo por el que en el art. 55 del antiguo Reglamento de Bie- 
nes de las Corporaciones Locales, de 27 de mayo de 1955, se establece que "Las Corporaciones Locales podrán recobrar por si la tenencia de sus bienes de dominio público en cualquier tiempo"; lo que se reproduce en el artículo 70 del nuevo Reglamento de 13 de junio de 1986.

Una vez rebatidos los argumentos empleados por el Ayuntamiento apelante, todos ellos desenvueltos a nivel de principios y de conceptos de carácter teórico, nos quedamos a solas con el contenido del Acuerdo recurrido, de 29 de octubre de 1957, y con el pronunciamiento del Tribunal de instancia. Lo que a su vez implica la inexistencia de argumentos que, en cuanto al fondo material del asunto propiamente dicho, y a la interpretación de los hechos realizada por la Sala de Oviedo, vengan a poner en cuestión el pronunciamiento emitido por ésta; situación parangonable a la dada en aquellas en que no evacúa .el trámite de alegaciones en estas alzadas procesales, lo que ha llevado a la jurisprudencia a declarar que ello conduce, ante la falta de un análisis critico de la sentencia (falta de análisis que aqui se da en el extremo en que hemos de resolver el litigio) si la sentencia apelada no incide en una manifiesta infracción legal, que pueda y deba ser corregida, sin menoscabo del carácter rogado de la Jurisdicción, a la confirmación de la sentencia del inferior: SS. 12 julio 1981; 28 enero, 26 febrero, 2 marzo, 30 marzo, 25 mayo 1982, 28 abril, 26 mayo, 20 julio, 13 octubre 1983; 27 y 30 noviembre y 31 diciembre 1984.

No obstante, no queremos aprovecharnos de esta doctrina para liberarnos de lo que normalmente constituye, para todo juzgador, la obligación de fundamentar debidamente, sobre todo las sentencias; si bien ésta se ve muy aliviada gracias al esfuerzo desplegado por el Tribunal de la Audiencia, quien en su tarea ha contado con el informe del Perito Agrícola, al que más atrás nos hemos referido, en el que, con todo detalle, y con la aportación de un croquis y unas fotografias, explica las dificultades que ofrece un tramo del camino en cuestión, en parte, se dice, por la pendiente importante a superar, y en parte, por las obras realizadas (por el denunciado) en un lateral del cobertizo dedicado a garaje presumiblemente para evitar la entrada de agua dentro de el, pero a costa del camino, que si bien en otros tramos tiene un ancho ya reducido de 2,50 metros, en el lugar que se describe, llega a reducirse a 2,14 metros.

Razón por la que el Tribunal "a quo", estimando la pretensión del accionante, dispone, tras anular el acuerdo recurrido, que la Corporación Local deberá adoptar las medidas necesarias para dejar el camino público en la situación anterior a la obra realizada por don Nemesio M.G., restableciendo la anchura primitiva del mismo.

Pronunciamiento que lo establece en base a la imprescriptibilidad de un bien que, como éste, es de dominio público, y contando 
con los preceptos legales que se recogen en el fundamento cuarto de su sentencia.

Sin que este pronunciamiento pueda ser puesto en cuestión por el hecho de la licencia de obras que el propio Ayuntamiento haya podido conceder, ya que al incidir sobre un bien de esta naturaleza, conlleva el que se la califique de licencia concedida por error, que, por eso, puede y debe ser anulada, restituyendo la cosa al ser y estado primitivo, tal y como se dispone en el art. 16.2 del Reglamento de Servicios de las Corporaciones Locales de 17 de junio de 1955.

(Sentencia de 6 de junio de 1990. Ar. 4813. MARTIN DEL BURGO y MARCHAN.)

\section{XI. - SERVICIOS PUBLICOS.}

\section{Adjudicación de puestos en mercado de abastos con ca- rácter de provisionalidad. Ocupación del suelo público. Distin- tos efectos de la precariedad.}

De toda la exposición anterior resulta que las autorizaciones o concesiones de puestos del mercado de Benicalap, aunque tenian un carácter provisional y de precariedad, siquiera ésta hubiera de interpretarse conforme a la doctrina de la Sentencia de la antigua Sala Cuarta de 11 de noviembre de 1986, como después se examinará, tenian un carácter indefinido, aunque sometido al condicionamiento de la construcción de otro mercado, este de carácter definitivo; esta situación va a durar hasta el Acuerdo plenario de 2 de julio de 1975, en el que se limita el tiempo de la concesión a un período de cuarenta años que, computados desde el 6 de marzo de 1957, concluyen en igual día del año, todavia no alcanzado de 1997; y, finalmente, las nuevas ordenanzas de mercados de 10 de diciembre de 1981 reconoce a los citados concesionarios el derecho a ocupar puestos en el nuevo mercado que se construya, con carácter preferente a toda otra persona, sin someterse a subasta y con el solo pago correspondiente al pago de las obras; ante esta situación es necesario plantearse como cuestión la relativa a si el Excmo. Ayuntamiento de Valencia, directamente o a través de la Junta de Compensación mencionada ha cumplido con las obligaciones que ha ido asumiendo y en un análisis concreto de las distintas actuaciones se ha de llegar a una conclusión negativa, por cuanto el Acto o Acuerdo impugnado de 13 de noviembre de 1986 no se adapta a la legalidad alcanzada.

De los dos conceptos usados en el Acto de 6 de marzo de 1957, provisionalidad y precariedad, el primero va a quedar anulado por la 
propia actuación municipal, al reconocer a los titulares de las licencias de ocupación, autorizaciones o concesiones en período de tiempo de duración concreto -cuarenta años- con posibilidades de continuar en el nuevo mercado que se construya si cuando ello no se ha alcanzado, como ha sucedido, la fecha limite del 6 de marzo de 1997; es decir, a partir del Acuerdo de 2 de julio de 1975, aunque la palabra provisionalidad se sigue utilizando, cual sucede en la autorización de transferencia de 4 de noviembre de 1977, ella ya no tiene el sentido de situación de duración incierta, por cuanto ésta ha quedado perfectamente definida por el acuerdo de modificación de ordenanza sí en cuanto al término precariedad, la sentencia citada, aunque referida a cuestiones relacionadas con instalaciones eléctricas, contiene una doctrina general relacionada con la ocupación de suelo público, que no es factible desconocer; en ella se distingue entre una precariedad de primer grado, la cual, por su poca profundidad y eficacia, queda reducida a una mera declaración semántica, incapaz de determinar toda limitación de la compensación indemnizatoria, originada por la actuación administrativa; en cambio, la de segundo grado, limita su eficacia al caso de que su aplicación venga determinada por la licitud de la revocación, modificación o reconversión del uso conferido, en razón al sentido, finalidad y contexto de la concesión o autorización otorgada, deduciéndose de ello que, cuando tales medidas se hallen encaminadas a la protección y salvaguardia del principal destino del bien de dominio público, sobre el cual recae el uso anormal, sólo, entonces, tendrá toda su eficacia la cláusula cuestionada, careciendo de ella en supuestos distintos; es más, como señala o añade la mencionada sentencia, esta doctrina ha supuesto, más que una modificación absoluta de los anteriores planteamientos, una profundización de los mismos para discernir en ellos cuando debe subsistir la hermenéutica anterior, siquiera sea a través de la ineficacia de la cláusula de precariedad y no de su anulación, y cuando ella adquiere relevancia en función de la finalidad perseguida, todo lo cual determina se traslade a un momento posterior al de su inserción, cual es el de su aplicación, la determinación de su eficacia, concretando que sólo se podrá realizar, cual señala la Sentencia de 29 de octubre de 1979, mediante la investigación del fin concreto del acto concesional o autorizante del uso, y el examen de las razones de oportunidad en que se apoya dicha revocación o modificación en relación con los planes o proyectos cuya realización determinan éstas.

Entrando, pues, en la citada investigación se observa que si bien es legitima la liberación de la vía pública de una instalación provisional o transitoria, ella no se debe hacer al margen de los derechos reconocidos a los titulares de los puestos concedidos o autorizados a 
partir del 6 de Marzo de 1957 y obvio es que ello no tuvo lugar por la actuación municipal, tanto si se considera desde el punto de vista de lo pactado entre el Excmo. Ayuntamiento de Valencia con la Junta de Compensación, como si se hace teniendo en cuenta la actuación de ésta en cumplimiento de tal pacto, pues al establecerse en aquel pacto unos precios claramente inadecuados a lo establecido por el art. 66 de las Ordenanzas, era obvio que la actuación de la citada Junta tampoco podía dar cumplimiento a lo por tal norma establecido o, al menos, nada de ello se ha acreditado en autos, como era obligado se hiciera a tenor de lo establecido por el art. 1214 del Código Civil y sin que sirva de excusa que los recurrentes en instancia conocían las nuevas condiciones, por cuanto, aunque es cierto se expusieron en la reunión de 22 de septiembre de 1982 no lo es menos que en aquel momento nada había decidido, como puso de manifiesto la Concejal Delegada de Mercados y que ellos fueron clara y expresamente contestados, conforme a la naturaleza que entonces tenían, por los interesados mediante el escrito de 30 de los mismos mes y año; y tampoco se alegue la actuación unilateral de la Junta de Compensación, por cuanto ello ni siquiera ha sucedido y de tal actuación resulta responsable, en definitiva, la Corporación a través del pacto establecido entre ésta y la Junta; en definitiva, se ha desconocido los derechos de los recurrentes $y$, al no darse las circunstancias de legalidad pertinentes, procede concluir que, ni se daban las circunstancias de desalojo o levantamiento del mercado provisional, ni la indemnización ofrecida, por las circunstancias y cuantía de su importe, puede estimarse la adecuada, aquélla, porque, además de no adaptarse cuantitativamente al citado articulo de las ordenanzas, no habría un nuevo periodo concesional que permitiera la adecuada amortización del capital que se invertía y ésta, porque caso de seguirse esa linea, la del simple rescate de la situación existente, para así poder llegar al cierre definitivo del mercado provisional antes de la conclusión del periodo establecido por la Corporación, no responde, como claramente se deduce del examen de la cláusula quinta del convenio con la Junta, a la realidad existente; que este convenio o el relativo al precio exigible infrinjan o desconozcan los derechos de los recurrentes en instancia, sólo a la Corporación hoy recurrente se debe, y aunque ella era libre de establecer los pactos que considerara pertinentes, no lo era sin, con simultaneidad, adoptar las medidas consiguientes para mantener los derechos de los citados recurrentes y como ello no deriva del acuerdo adoptado y objeto de impugnación, procede confirmar la sentencia de instancia, desestimando el recurso de apelación y sin que para ello fuera necesario examinar si con la actuación municipal en el convenio con la Junta se infringían o no otros artículos de la Ordenanza, pues 
ello es materia que desborda totalmente el ámbito de este recurso jurisdiccional y no era necesario abordar, bastando lo dicho para llegar al fallo establecido, habida cuenta que por las circunstancias del caso es claro nos hallamos ante una situación de precariedad de segundo grado, cual se ha indicado $y$, aunque la finalidad última del acto era y es legitima, ella no se puede obtener por unos medios que como se señala al final del cuarto fundamento de derecho de la Sentencia de 11 de noviembre de 1986, suponía una actuación arbitraria, total y absolutamente incompatible con la doctrina establecida sobre interdicción de la arbitrariedad.

(Sentencia de 30 de abril de 1990. Ar. 3671.I. JIMENEZ HERNANDEZ.)

2. Transportes urbanos. Expediente de elevación de tarifas.

Debe perseguir el equilibrio de la equación precio-costes en un intento de armonizar el interés público con el normal desarrollo de la actividad empresarial. Competencias del Gobernador Civil.

Se impugna en este proceso por la empresa concesionaria del servicio público municipal de transportes urbanos de Granada Transportes R., S.A., la resolución de la Comisión Delegada del Gobierno para asuntos económicos, que desestimó el recurso de alzada interpuesto por la misma empresa contra la Resolución del Gobernador Civil de Granada de 29 de enero de 1979, por la que se aprobaron las tarifas del servicio público de transportes urbanos de aquella capital, postulándose además en el suplico de la demanda la declaración del derecho de la recurrente a ser indemnizada por los perjuicios sufridos durante el tiempo en que estuvieron vigentes las tarifas aprobadas el 29 de enero de 1979, cuya cuantía se establece en $9.961 .420,58$ pesetas, actualizadas a la fecha en que se proceda a la ejecución de sentencia, mediante la aplicación a la misma de los indices de precios al consumo, mas los intereses legales de la cantidad resultante que ésta haya podido devengar desde 1979 hasta que por la Administración se proceda a su pago.

El origen de la presente controversia se remonta a la fecha del 2 de noviembre de 1978, cuando la empresa concesionaria, con arreglo a la cláusula del pliego de condiciones que prevé la revisión extraordinaria de las tarifas, presentó ante el Ayuntamiento el estudio económico y propuesta de modificación de aquéllas, justificando la insuficiencia de las anteriores. La citada Corporación Municipal adoptó por unanimidad acuerdo favorable remitiendo el expediente al Gobernador Civil. Recabados los informes preceptivos se dictó por 
este Centro la Resolución de 29 de enero de 1979, en la que se fijaron las tarifas: trayecto 8,50 pesetas, subida a 10 pesetas; el de 9 a 10,50 (la empresa proponía 11) , el de 10 a 11,50 (la empresa proponía 12) y el de 10,50 a 12 (la empresa proponía 13). De acuerdo con el informe de la Comisión Provincial de precios el nuevo régimen tarifario, quedaba condicionado a que por la empresa se propusiera la creación de un billete de ida y vuelta en días laborables al que se daría la tramitación legal oportuna.

Prescindiendo de las vicisitudes del tracto impugnatorio, derivado de la omisión de requisitos esenciales en la notificación del acto originario determinante de una reconducción a la vía procedente, con trascendencia dilatoria, el recurso contiene una doble pretensión, de un lado la nulidad de las resoluciones administrativas de primer grado y alzada y en segundo término, la indemnización de daños y perjuicios producidos por el margen de elevación inaceptado de las tarifas revisadas durante el período durante el cual debieron aplicarse en su integridad con arreglo al informe motivado de la Corporación Municipal. Respecto de la primera cuestión el artículo $8^{\circ}$ bis del Decreto 2226/1977 de 27 de agosto, que modificó el anterior de 20 de diciembre de 1974, en lo relativo a autorizaciones de aumento de tarifas de servicios de competencia local, dispone que los expedientes se tramitarán inicialmente por la Corporación titular del servicio a instancia del órgano o Entidad Gestora o concesionaria del mismo. A la petición deberá acompañarse el estudio económico previsto por el articulo 18 apartado $1^{\circ}$ de la Ley 48/1966 de 23 de julio. La Corporación emitirá informe motivado sobre la elevación solicitada, precisando con exactitud las cantidades o porcentajes de aumento que estime adecuados y elevará el expediente completo al Gobernador Civil de la Provincia. El Gobernador Civil someterá el expediente a informe de la Comisión Provincial de precios y en especial de los servicios provinciales de los Ministerios competentes por razón de la materia. Evacuados estos trámites el Gobernador Civil dictará resolución fijando la cuantía concreta de la elevación, que en ningún caso podrá exceder del máximo fijado por la Corporación en su informe. Del mencionado precepto se desprende que lo único que el Gobernador puede hacer, es una rebaja en la cuantía de las tarifas propuestas, pero ya de suyo que esta actitud debe responder siempre a causas fundadas en la razón de ser del expediente de revisión, de modo que el margen de incremento aprobado corresponda realmente al incremento de los costes producidos desde la aprobación de la tarifa anterior. Es cierto que el Gobernador goza de un cuerpo de asesores, pero el carácter no vinculante de sus informes, no le obliga a asumirlos, si de su examen se 
desprende que no prevalece en ellos la debida equiparación entre el incremento de los costes y el aumento de las tarifas.

Como se argumenta en la demanda si las cifras de incremento de costes que el propio Ayuntamiento acepta, no se han objetado por la Jefatura Regional de Transportes, la rebaja de las tarifas propuestas, ha obedecido solamente a la consideración del periodo de tiempo a que afecta la revisión, que aun computándose entre las fechas de aprobación de las tarifas anteriores y la entrada en vigor de las revisadas, superó en dos meses el cálculo de dicha Jefatura, al suponer sin fundamento que el expediente se resolvería en menor plazo. En consecuencia el incremento de costes en dicho intervalo no fue tenido en cuenta y constituyó la única causa de que el margen de elevación no llegara al pretendido por la empresa. Aparece así de esta insuficiencia en la motivación del informe, que no desvirtúa las conclusiones del estudio económico acompañado con la propuesta, la primera infracción del ordenamiento jurídico, pues el sentido general de la normativa sobre política de precios y en concreto el articulo $3^{\circ}$ del Real Decreto de 28 de octubre de 1977, apuntan la tendencia de equilibrar la ecuación precio-costes en el intento de armonizar el interés público con el normal desarrollo de la actividad empresarial, pero es que además la Resolución del Gobierno Civil de Granada impone, una condición extraña al expediente, para la entrada en vigor de las tarifas, supeditada a que previamente la empresa proponga al Ayuntamiento la creación de un billete de ida y vuelta en días laborables. Esta exigencia infringe el citado articulo 8 bis del Decreto 2226/1977 pues los expedientes deben tramitarse, sin ningún tipo de excitación oficial, a instancia del órgano o entidad gestora o concesionaria del mismo, de tal modo que no se influya ni se anule su capacidad de iniciativa y menos bajo la indisimulada presión de no permitir que entren en vigor las nuevas tarifas hasta que se cumpla la condición impuesta, pues como hemos dicho el Gobernador Civil tiene competencia para rebajar las tarifas, si la elevación propuesta resultara excesiva en relación con los costes, pero carece de ella para imponer modalidades no formuladas en el expediente inicial y condicionar al cumplimiento de este requisito la efectividad de las tarifas aprobadas después de su modificación.

Aunque la nulidad de los acuerdos impugnados por las razones expuestas haga innecesario referirse a la imposibilidad de cumplimiento de las tarifas aprobadas por falta de moneda fraccionaria adecuada, no cabria estimar acreditado que el valor numismático de las monedas de 0,50 pesetas en 1979, las hubiera puesto fuera de circulación, en primer lugar porque ese mercado está en función de la rareza pero no de la inexistencia y sobre todo porque si el argumento sirviera para olvidar 
que la cuantía de las tarifas viene principalmente influida por la necesidad de mantener la ecuación financiera, también hubiera podido utilizarse por el Gobernador Civil para redondear a la baja. De haber ocurrido así la empresa recurrente hubiera compartido la tesis que propugnamos. Así mismo la desviación de poder, por naturaleza incompatible con la nulidad resultante de la infracción de preceptos concretos del Ordenamiento Jurídico, nunca podría apreciarse a través de gratuitas imputaciones electoralistas, cuando la decisión, aun equivocada de la autoridad actuante viene respaldada por una información técnica, a cuyos redactores no cabria atribuirles la misma desviación, de no mediar una sumisión y falta de profesionalidad, que sin más fundamento que la opinión de la parte actora, es de todo punto temerario presumir.

(Sentencia de 4 de mayo de 1990. Ar. 4238. A. LLORENTE CALAMA.)

XII.- URBANISMO.

1. Interpretación del art. 70.2 de la LBRL. Necesidad de publicación completa de todos los planes urbanísticos, no sólo de aquellos cuya aprobación definitiva es la competencia municipal.

Desde luego podría pensarse que las exigencias del art. 70.2 son sólo de aplicación en los casos de aprobación definitiva de la competencia municipal:

A) El inciso primero del precepto va referido a los acuerdos de las Corporaciones locales y esto da base para entender que su ámbito es únicamente el de las aprobaciones definitivas que son competencia de aquéllas.

B) El plazo de vacatio legis se fija por remisión al art. 65.2 de la propia Ley. Ciertamente es un plazo extraño tanto por sus dies a quo como por su cómputo de días hábiles. No es este el momento de precisar ahora aquel dies a quo -razones de fijeza y seguridad jurídica exigen la adaptación al terreno que se contempla: publicación y entrada en vigor de normas-. Pero si que hay que indicar que aquella remisión a un precepto que regula la impugnación de acuerdos locales podría venir a corroborar la tesis recogida en el apartado A).

Sin embargo una reflexión más detenida sobre el tema conducirá a otra conclusión: 
A) En el terreno de la pura literalidad, el precepto va dirigido a las ordenanzas "incluidas las normas de los planes urbanisti$\cos ^{\prime \prime}$. Y no se hace distinción alguna. Cabe pensar que pese a las sedes materias se ha querido introducir una norma de sentido rigurosamente urbanístico.

Es más, la Ley de Bases era perfectamente consciente de la novedad que establecía y de su gran trascendencia y por ello para evitar atenuaciones y restricciones regula la consecuencia juridica de forma negativa: "...las normas de los planes urbanísticos... no entran en vigor hasta que se haya publicado completamente su texto y haya transcurrido el plazo... ".

Y ello Sin distinción alguna.

B) Desde el punto de vista de la lógica juridica y en muy directa relación con la finalidad de la normativa que se examina no resulta en modo alguno explicable que los planes de menor trascendencia -art. 5․1 del Real Decreto-Ley 16-1981, de 16 de octubre- estén sometidos a las rigurosas exigencias del art. 70.2 de la Ley 7-1985 y en cambio un Plan General de Ordenación Urbana, de mucha mayor relevante, pueda entrar en vigor sin publicidad alguna para las normas definitivamente aprobadas.

C) El hecho de que el art. 70.2 de la Ley 7-1985 vaya referido a las Ordenanzas Locales no implica una exclusión de las normas de los planes urbanísticos: los planes del escalón municipal no pierden su carácter subjetiva y objetivamente aprobados por la Administración autonómica. En efecto:

a) La diversidad de intereses presentes en el campo del urbanismo hacen de la de planeamiento una potestad de titularidad compartida por los Municipios y las Comunidades Autónomas. Su actuación se lleva a cabo a través de un procedimiento bifásico en el que a la aprobación provisional del Municipio, en lo que ahora importa, sigue en el tiempo la definitiva de la Administración Autonómica.

Partiendo de la base de que "en la relación entre el interés local y el interés supralocal es claramente predominante este último" -Sentencia del Tribunal Constitucional 170-1989, de 19 de octubre- queda perfectamente justificado que, en el aspecto temporal, la decisión autonómica se produzca con posterioridad a la municipal y que, en el aspecto sustantivo, aquélla haya de contemplar el plan no sólo en sus aspectos reglados sino también en los discrecionales que por su conexión con intereses supralocales hayan de ser valorados para asegurar una coherencia presidida por la prevalencia de tales intereses superiores. 
Pero aun siendo esto así, lo que ahora se destaca es la existencia de unos intereses locales en el planeamiento que justifican la participación municipal en la competencia.

Precisamente en la reciente Sentencia de 20 de marzo de 1990 esta Sala destacaba el carácter municipal de aquella competencia para justificar una doble legitimación autonómica y municipal independientemente de lo que pudiera derivar de los arts. 237.2 del Texto Refundido de la Ley del Suelo y 29.2 de la Ley Jurisdiccional: aunque el acuerdo autonómico contenga modificaciones no podrá olvidarse la legitimación pasiva del municipio.

La de planeamiento es una competencia compartida y por ello resulta bien claro el carácter subjetivamente municipal del plan que no queda eliminado por la aprobación definitiva autonómica.

b) En otra linea el planeamiento del escalón municipal, en razón del ámbito territorial de su vigencia, tiene claramente ese sentido local: traza el marco físico en el que va a desenvolverse la convivencia de la población del Municipio.

En definitiva, esta naturaleza del planeamiento justifica plenamente la aplicación de una normativa prevista para las Ordenanzas locales.

D) En último término será de recordar el principio de interpretación conforme a la Constitución de todo el ordenamiento jurídico -art. 5․ 1. de la Ley Orgánica del Poder Judicial-. La Constitución es un contexto dominante para todas las demás normas lo que exige que las dudas surgidas en la interpretación de éstas hayan de ser resueltas en el sentido que mejor contribuya a hacer realidad el modelo de convivencia que aquélla dibuja.

Lo que aquí se está discutiendo es si han de publicarse o no determinadas normas -normas son pues la calificación de urbanísticas no puede borrar aquella naturaleza; hay en este sentido una copiosa jurisprudencia-. Pues bien, proclamado por la Constitución el principio de la publicidad de las normas -art. 9.3-, es claro que toda duda ha de despejarse con la solución que permita hacer más eficaz dicha publicidad y en esta linea el examen comparativo de los sistemas de la Ley del Suelo y del art. 70.2 de la Ley 7-1985 conduce claramente a la conclusión que ya derivada de los razonamientos anteriores.

En definitiva la amplia dicción literal del art. 70.2 de la Ley Reguladora de las Bases del Régimen Local, referida a los planes urbanísticos sin distinción, el carácter municipal del planeamiento en alguno de sus escalones, la lógica que excluye que en los planes de mayor 
relevancia la publicidad sea menor y en último término el principio de interpretación conforme a la Constitución que en su art. 9.3 consagra el principio de publicidad de las normas, conducen a la conclusión de que el art. 70.2 de la Ley 7-1985 no puede referirse sólo a los planes cuya aprobación definitiva es de la competencia municipal.

Dado que en el supuesto litigioso las normas urbanisticas de la Revisión y Adaptación del Plan General de Ordenación Urbana de Palma de Mallorca no fueron publicadas dentro del plazo de otorgamiento de la licencia discutida ni en el Boletín Oficial de la Comunidad ni tampoco en el de la Provincia no resulta necesaria ahora la búsqueda de la solución que concilie los arts. 70.2 de la Ley 7-1985 y 36 del Estatuto de Autonomia de las Islas Baleares.

Tal falta de publicación impedía la entrada en vigor del Plan que por tanto no podía servir de fundamento para la denegación de la licencia litigiosa cuyo otorgamiento con arreglo al planeamiento anterior era procedente.

En este sentido ha de ser estimada la apelación en cuanto a la petición subsidiaria pues no cabe entender otorgada la licencia por silencio administrativo positivo.

En efecto, esta Sala viene declarando que tanto por razones de celeridad y eficacia de la actuación administrativa como por respeto a la autonomía municipal ha de entenderse que el Municipio, incluso cuando ha transcurrido el plazo de dos meses previsto en el art. 9o. 1. $5^{\circ}$ del Reglamento de Servicios -art. 49 de la Ley de Procedimiento Administrativo- y ya se ha denunciado la mora ante la Comisión -art. 9․ 1.7․a) del citado Reglamento-, puede resolver válidamente respecto de las solicitudes de licencia hasta el momento en que reciba el requerimiento de la Comisión para la remisión del expediente -Sentencia de 30 de diciembre de 1989-.

No hubo, pues, silencio positivo y por tanto la estimación de la apelación ha de referirse a la petición subsidiaria del escrito de demanda.

(Sentencia de 10 de abril de 1990. Ar. 3593. J. DELGADO BARRIO.)

2. Sistema de compensación. Bases de actuación y proyecto de compensación. No es el proyecto de compensación el que abre la posibilidad de proceder a la ejecución del plan, previa la obtención de las licencias oportunas, sino las Bases de actuación.

La única forma de corregir tan desafortunada actuación urbanística era la constitución de la Junta de Compensación, que hemos visto se produjo el día 26 de julio de 1983, momento en que puede consi- 
derarse en ejecución el Plan Parcial e iniciarse el desarrollo de las actuaciones necesarias a través de las pertinentes obras de urbanización. Efectivamente, como decimos ha habido una actuación irregular, pues se inició la ejecución de un Plan Parcial que establecía para la misma el sistema de compensación sin estar constituida la Junta correspondiente. Ahora bien, una vez constituida ésta para la ejecución de un poligono o unidad de actuación con solidaridad de beneficios y cargas entre los propietarios del suelo -art. 157.1 R.G.U.- rige su vida por el principio democrático de las mayorías simples de cuotas de participación, salvo que en los Estatutos o en otra norma se establezca un "quorum" especial para determinados supuestos; a este respecto, los Estatutos de la Junta de Compensación de los Sectores S-10 y S-10-A de Trillo, en su artículo 27, apartado 5, dispone que los acuerdos se adoptarán por mayoría de votos presentes o representados, por lo que si en el ejercicio de su soberanía, dentro del ámbito de sus competencias y con respeto a la legalidad urbanística, la Junta de Compensación adopta decisiones por mayoria, éstas son legitimas por más que se oponga una minoría. Lo anterior determina, en relación con el acuerdo $2^{\circ}$ de la Asamblea celebrada el 5 de septiembre de 1983 y los acuerdos $4^{\circ}, 5^{\circ}, 6^{\circ}$ y $7^{\circ}$ de la celebrada el día 7 de octubre del propio año, que si la Junta de Compensación decidió hacer suyas y asumir las obras realizadas con anterioridad por uno de sus miembros, así como los gastos que ello ha originado y concluir su ejecución, habiéndose adoptado dichos acuerdos por mayoría de cuotas de participación, siempre y cuando las cargas derivadas para hacer frente a dichos gastos y obras de urbanización se repartan proporcionalmente entre los propietarios afectados en relación a las cuotas de participación, como ha ocurrido en el supuesto debatido, el recurrente debe aquietarse a tales decisiones y consentir con lo que ha decidido la mayoría de la Junta de Compensación. La anterior conclusión está fuera de toda duda, máxime cuando la forma de proceder de la Junta de Compensación es la única posible para legalizar las obras ejecutadas indebidamente por U.E.F., S.A., so pena de concluir, como hace el recurrente en que lo procedente es la demolición de todo lo indebidamente construido para después proceder a realizar nuevas obras, lo cual pugna con la más elemental lógica, no ya jurídica, sino simplemente humana.

También pretende el señor C.G. que se anule el acuerdo $4^{\circ}$ de la Asamblea celebrada el día 5 de septiembre, por el que se decidió que la Junta de Compensación solicitase del Ayuntamiento de Trillo licencia de urbanización, utilizando como argumento que en tanto no se aprueba el Proyecto de Compensación no puede realizarse obra de urbanización alguna y, por lo tanto, no es posible deducir solicitud 
alguna de licencia de urbanización. Pues bien, con independencia de que el acuerdo impugnado es una mera declaración de intenciones, correspondiendo al Ayuntamiento, de ser cierta la tesis mantenida por el recurrente, la denegación de la licencia, dicha tesis no es sostenible por cuanto no es el Proyecto de Compensación el que abre la posibilidad de proceder a la ejecución del Plan, previa la obtención de las oportunas licencias, sino las Bases de actuación, como cabe deducir del texto del articulo 167 del Reglamento de Gestión urbanística, limitándose aquél, de acuerdo con los criterios fijados por éstas, a describir las propiedades antiguas y las nuevas, a localizar los terrenos de cesión obligatoria y de reservas y la superficie que la Junta se reserve para, en su caso, proceder directamente a su enajenación a fin de sufragar los gastos previstos de la urbanización y, finalmente, a fijar las compensaciones en metálico que procedan (art. 172 R.G.U.), y como quiera que en el presente caso las Bases de actuación fueron aprobadas el 31 de mayo de 1983, no existía obstáculo alguno para deducir la solicitud de licencia.

Finalmente, se impugna también el Acuerdo $2^{\circ}$ de la Asamblea celebrada el dia 7 de octubre de 1983 por el que se aprobó el Proyecto de Compensación. El proyecto de compensación, una vez sometido a audiencia de los interesados, se aprobará por el acuerdo de la mayoría de los Miembros de la Junta de Compensación que a su vez representen las dos terceras partes de las cuotas de participación (art. 174.1 R.G.U), debiendo en todo caso seguir los criterios fijados en las Bases de Actuación (art. 172 R.G.U.). Aquellos requisitos han sido cumplidos y no consta que el Proyecto no siga los criterios fijados por éstas, por lo que no hay motivo alguno para mantener la falta de conformidad a Derecho y consecuente nulidad del mismo, sin que tenga virtualidad alguna a estos efectos la alegación del recurrente relativa a que dicho Proyecto es una simple acomodación a lo ilegalmente construido por U.E.F., S.A., porque, en primer lugar, por lo argumentado en el tercer fundamento jurídico de esta resolución, nada se opone a que la Junta de Compensación, en el ejercicio de sus competencias y mediante acuerdo adoptado por la mayoria, así lo decida, si aquellas obras son conformes con la legalidad urbanística; $y$ en segundo lugar, porque tal modo de proceder era el único posible para adecuar al ordenamiento jurídico la previa actuación disconforme con el mismo.

Consecuencia de los precedentes razonamientos jurídicos es que la petición principal formulada por la representación procesal de don Angel C.G. debe ser integramente rechazada. Igual suerte han de seguir las pretensiones subsidiariamente deducidas porque, respecto a la petición de que se le indemnice en la cantidad de 500.000 pesetas 
como consecuencia de la ubicación que se hace en el Proyecto de Compensación de la finca que se le adjudica no acredita la existencia de los datos y perjuicios, que, según su criterio, ello le irroga, lo que es presupuesto ineludible para el nacimiento del derecho a ser indemnizado, sin que tenga virtualidad alguna a estos efectos la mera alegación de que aquella localización supone una depreciación de su parcela en atención a que se coloca junto a un terreno para dotación social y comercial muy lejos de la zona verde privada donde tendrian más valor, pues es una mera apreciación subjetiva, en todo caso discutible y falta de cualquier dato objetivo que la fundamente. Respecto de la petición relativa a que los gastos a que debe él hacer frente, en su correspondiente cuota de participación, no son los realmente efectuados, sino los inicialmente presupuestados en los Proyectos de Urbanización de los Sectores S-10 y S-10-A (que dicho sea de paso, fueron anulados por esta Sala a su instancia), pues de concluirse asi se quebraría el principio de igualdad y justa distribución de los beneficios y cargas derivados del planeamiento, que ha de presidir toda actuación urbanística -art. 3.2. b T.R.L.S.-, pues en todo caso el recurrente se va a beneficiar en cuanto propietario y miembro de la Junta de Compensación de las obras de urbanización ejecutadas o que se ejecuten en el importe real de su ejecución, el cual determina a su vez, junto con otros factores, su valor en el mercado, es decir, en aquella condición se va a beneficiar de las obras ya realizadas por lo que no puede pretender no participar en los gastos que dichas obras han originado, finalmente, respecto a la petición relativa a que las obras que ejecutó U.E.F., S.A., se paralicen, porque ello fue acordado ya en la Sentencia no 3 de 1988, dictada por esta Sala el día 20 de enero de 1988 en el recurso $n^{\circ} 92 / 54$, ya citada.

Conviene, antes de concluir, precisar que la incorporación a una Junta de Compensación no es obligatoria para los propietarios afectados, tal y como cabe deducir de los artículos 126.2 y 127.1 del Texto Refundido de la Ley del Suelo y 161, 162 y 163.2 del Reglamento de Gestión urbanística, pudiendo optar por que su finca o parcela sea expropiada (art. 127.1 T.R.L.S.). Nadie ha obligado, pues, al recurrente a incorporarse a la Junta de Compensación de los Sectores S-10 y S-10A de Trillo; ahora bien, si él en el ejercicio de su libre voluntad ha decidido incorporarse a la misma no puede apoyarse en defectos formales, como los que motivaron el reiteradamente citado recurso 92/84, siempre legalizables para obstaculizar la obra urbanizadora en detrimento de los intereses de los demás propietarios incorporados a la misma, que representan la mayoria, y del interés publico, siempre presente en toda actuación urbanística, y en exclusivo beneficio del suyo propio privado y minoritario. 
Las argumentaciones del apelante en su escrito de alegaciones carecen de la virtualidad suficiente para contradecir los sólidos razonamientos de la Sala Tercera de Madrid, que en los fundamentos de derecho de su sentencia ha examinado toda la problemática suscitada en el recurso sometido a su decisión dando una atinada respuesta a todas las cuestiones planteadas, razón por la que se impone la desestimación de la apelación. En efecto, la incorporación del recurrente a la Junta de Compensación de los sectores S-10 y S-10-A de Trillo, incorporación totalmente voluntaria, supuso para el mismo su sometimiento a todos los acuerdos que en el marco de la legalidad pudiese adoptar la junta y, por tanto, a que ésta decidiese asumir todas las obras de urbanización ejecutadas antes de constituirse por uno de los integrantes de ella, obras que no sólo beneficiaban al miembro mayoritario de la misma que las había realizado, sino al propio recurrente como propietario de una porción de suelo comprendida en el ámbito del Plan Parcial a ejecutar por el sistema de compensación, quedando obligado a contribuir al coste de tales obras y de las posteriores en proporción a su interés en la Junta, sin que a ello pueda válidamente objetar con la ilegalidad de las primeras cuando esta ilegalidad era meramente formal, consecuencia de haberlas realizado sin licencia, $y$ la licencia fue en definitiva otorgada por acuerdo de 30 de noviembre de 1983. El que la Junta de Compensación acordase en su reunión del 5 de septiembre de 1983 solicitar la licencia de urbanización constituyó una decisión total y absolutamente indiferente para el recurrente, al que mal se le puede entender legitimado para combatirla, y máxime cuando el Ayuntamiento de Trillo vino a rechazarla en el punto $3^{\circ}$ de su Acuerdo de 26 de octubre de 1963, resolutorio del recurso de alzada.

La impugnación del Acuerdo de 7 de octubre de 1983 por el que la Junta de Compensación decidió aprobar el Proyecto de Compensación, aparte de combatir a un acto irrecurrible, por cuanto según se desprende del contenido del articulo 174 del Reglamento de Gestión Urbanística el acto que culmina el procedimiento no es la aprobación del Proyecto de Compensación por la Junta, sino su definitiva aprobación por el Ayuntamiento, el Acuerdo de 26 de octubre de 1983 del de Trillo al particular no ha sido objeto del recurso, carece de la más mínima consistencia, ya que en la adjudicación de fincas resultantes es una actuación por el sistema de compensación lo decisivo son las Bases de Actuación, tal como lo dispone el artículo 167.1. g) del aludido Reglamento, no lo ordenado por el artículo 99.1. c) de la Ley sobre Régimen del Suelo y Ordenación Urbana, el que además no puede decirse que haya sido vulnerado cuando lo que dispone no es forzoso $y$, por otra parte, en su desarrollo reglamentario por el artículo 95 del 
Reglamento de Gestión se excluye de su prevención al supuesto de estar el terreno en suelo destinado a viales o zonas verdes, cual sucede con la finca del apelante. Finalmente, las pretensiones subsidiarias del recurrente necesariamente habian de ser desestimadas, en un punto, por la más absoluta falta de prueba de que la finca que le fue adjudicada le supusiese un perjuicio $y$, muchísimo menos, el que éste exigiese una indemnización de quinientas mil pesetas, y en otro aspecto, por la simple razón de que los costes a asumir por los componentes de una Junta de Compensación no son los inicialmente presupuestados, sino los reales a que hayan ascendido los gastos efectuados, sin que acerca de la realidad de los cometidos a la aprobación de la Junta de Compensación de los Sectores S-10 y S-10-A de Trillo y avalados por las correspondientes certificaciones se haya acreditado nada en contrario.

(Sentencia de 24 de mayo de 1990. Ar. 4280. BARRIO IGLESIAS.)

3. Edificación forzosa. Implica una expropiación con beneficiario privado. La carga edificatoria abstracta se concreta a través del Registro Municipal de Solares, que también individualiza las consecuencias de su eventual incumplimiento. Necesidad de declaración formal de incumplimiento del plazo.

"Como es bien sabido la institución de la edificación forzosa de los "solares yermos", bajo sanción de expropiación es conocida desde el antiguo Derecho histórico, y llega hasta la Ley del Suelo de 1956 y a la vigente cuyo texto refundido se aprueba por Real Decreto 1346/76 de 9 de abril, que declara, a su vez, la vigencia del Reglamento de Edificación Forzosa y Registro Municipal de Solares, aprobado por Decreto 635/64 de 5 de marzo, tratándose con ella de impedir la retención indefinida de solares a base de forzar, bajo la intimación expropiatoria, a edificar, al propietario que no esté dispuesto a hacerlo por si o vender su solar a un promotor de construcciones con lo que se ocasionará una movilización de solares que, al aumentar la oferta, reducirá su precio en el mercado, como expresan los preámbulos de dichas disposiciones, a cuyos propósitos provee el artículo 154 de la Ley del Suelo cuando dispone que el propietario de solares deberá emprender la edificación dentro del plazo fijado, lo que más bien constituyen una carga que un deber en cuanto que supone simplemente la necesidad de adoptar un determinado comportamiento para obtener un beneficio o para evitar un perjuicio, y porque su incumplimiento no da lugar a ejecuciones forzosas ni a sanciones personales sino a la consecuencia desfavorable de la expropiación forzosa, lo que se halla de acuerdo con la "función social" que a la propiedad 
impone el artículo 33.2 de la Constitución Española, y tanto si se denomina "venta forzosa", como sucede en la Ley -artículos 156, 158.2 y 160.1- como si se le atribuye el carácter de "enajenación forzosa", como acaece en el Reglamento de referencia (capitulos VII y VIII ), lo cierto es que implica una expropiación con beneficiario privado y que supone eliminar al propietario que ha desatendido la carga de edificar para sustituirlo por otro que se muestre dispuesto a ello, siendo de destacar que tal carga edificatoria abstracta se concreta a través del Registro Municipal de Solares que también individualiza las consecuencias de su eventual incumplimiento, dando lugar la inclusión de la finca en el Registro al comienzo del cómputo del plazo de dos años para edificar, según los artículos 154.3 y 156.2 de la Ley del Suelo y 4 del Reglamento de Edificación Forzosa, por lo que la inclusión es aquí constitutiva de la carga de edificar, así como a la iniciación del expediente de valoración, a tenor del artículo 157 de aquella Ley, de lo que, ya en relación concreta con el supuesto de autos, ha de deducirse que la inclusión de la finca en el Registro Municipal de Solares e Inmuebles de Edificación Forzosa, decretada por esta Sala en Sentencia de 2 de octubre de 1972 (Recurso 7/72) y llevada a efecto por Resolución de 28 de junio de 1973 de la Comisión Municipal Permanente, debidamente notificada, hubo de determinar, sin duda, el "dies a quo" a partir del cual se computaria el mencionado plazo a efectos de que, una vez cumplido, pase a poder declararse el incumplimiento de la carga si no se ha iniciado la construcción o, aun iniciada, no se ha desarrollado "al ritmo normal previsto", a tenor del artículo 25 del Reglamento mencionado y del artículo 156,2 de la mencionada Ley, declaración que constituye título expropiatorio para desapoderar coactivamente al propietario incumplidor $y$, como se dijo, a sustituirlo por otro dispuesto al cumplimiento, como prueba el hecho de que en el asiento del inmueble en el Registro se acredita la concurrencia de todos los requisitos legales de la expropiación, quedando sólo pendiente la consumación de dicha expropiación, según los artículos 158 y 159 de la Ley de referencia."

Con relación a dicho plazo el Tribunal Supremo en Sentencia como las de 15 de abril y 15 de diciembre de 1960, 6 de abril de 1962, 21 de febrero y 10 de octubre de 1966, 28 de febrero de 1975, 22 de diciembre de 1987, ha declarado que tal plazo no constituye, ni puede constituir, por su naturaleza, un término inexorable, sino que está relacionado siempre con las posibilidades de exigirlo, y que en el momento de decidir sobre el incumplimiento de la obligación de edificar dentro de aquel plazo han de tenerse en cuenta las circunstancias objetivas que concurran en cada caso, así como que el derecho de retención de la finca concedido al propietario sólo puede entenderse 
caducado ante la inacción de su titular que sea suficiente a establecer una presunción de abandono por su parte de su obligación a edificar, sin que, no obstante, dicho plazo pueda alterarse por actos u omisiones voluntarias del propietario, porque "no se produce automáticamente el incumplimiento por el mero transcurso de los plazos cuando existe una voluntad persistente por parte de los obligados de cumplir con la obligación", más, si bien se observa, resulta que tal declaración de incumplimiento de la carga de edificar, precisamente porque ha de partir de tales consideraciones y ha de descender a la realidad de los hechos y sus circunstancias, al no ser "automática", requiere, según el artículo 25,2 del Reglamento mencionado, una tramitación similar, en lo pertinente, a la establecida en los artículos 15 a 17 del mismo, lo que implica, obviamente, la incoación de un expediente en el que aquélla se notificará al propietario de la finca, ocupantes y titulares de derechos reales, en su caso, y se publicará en los periódicos a que alude el artículo 15,b) del Reglamento, con el fin de que los interesados puedan alegar lo que estimen conveniente y aportar o proponer pruebas, $y$ en cuyo expediente, tras el informe de los Servicios Jurídicos y de los Técnicos, en su caso, o del Letrado y Arquitecto, se emitirá una propuesta que se someterá al Ayuntamiento, recayendo entonces el acuerdo pertinente, que será notificado y contra el que cabrá constatar en el Registro de la Propiedad, según los artículos 26 y 27 del Reglamento, donde tendrá carácter de carga real que advierte de la eventual expropiación de la finca.

A diferencia de lo que ocurriera en el supuesto de los recursos acumulados 386 y 387 de 1987, que fue el que dio lugar a la Sentencia del Tribunal Supremo antes mencionada de 10 de octubre de 1988, en el que el Ayuntamiento demandado accedió "a la incoación del expediente correspondiente, relativo al pretendido incumplimiento de la obligación de edificar, en el cual, después de conceder audiencia a la propietaria y emitidos los informes que se estimaron pertinentes, se adoptó el acuerdo... " por el que se declaró "no haber lugar, por el momento, a declarar el incumplimiento mencionado", según literalmente se transcribe de la Sentencia de esta Sala de 5 de marzo de 1987, referida a los mencionados recursos, en el supuesto de autos lo que ha sucedido es que "ab inicio" la Administración demandada ha denegado "la solicitud de incoación del expediente para declarar incumplida la obligación de edificar", de lo que resulta que más que declarar o de no declarar incumplida tal obligación, como parecen entender todas las partes, ha omitido el trámite correspondiente, que ha de ser inexcusablemente previo a cualquiera de tales resoluciones y de ello se deduce la procedencia de anular los actos recurridos por no ser conformes a Derecho, debiendo ser sustituidos 
por otro de incoación del expediente a que se hizo referencia en el fundamento de derecho anterior para llegar a declarar, en forma motivada y en su caso, el incumplimiento de la obligación de edificar, con la consiguiente estimación en cuanto a ello del recurso interpuesto, que ha de ser desestimado en lo que respecta a los otros pronunciamientos solicitados por la parte actorar por no corresponder verificarlos en esta sentencia al no haber podido resolver sobre ellos la Administración sin la tramitación pertinente de referencia.

\section{FUNDAMENTOS DE DERECHO (Tribunal Supremo)}

Se aceptan los de la sentencia apelada.

PRIMERO. - La sentencia de la Sala de lo Contencioso-Administrativo de la Audiencia Territorial de Las Palmas, ahora apelada por Don Emilio L.N. y por el Ayuntamiento de Las Palmas de Gran Canaria de 22 de septiembre de 1986, en la que se acordó denegar la solicitud de incoación de expediente para declarar incumplida la obligación de edificar respecto al inmueble $n^{\circ} \mathbf{2 6}$ de la calle Triana y 25 de la de Francisco Gourié y su consiguiente venta forzosa, por no considerarlo factible, al menos por el momento; la confirmación de esta resolución, al denegar por silencio administrativo el recurso de reposición entablado contra ella; y la Resolución expresa de 2 de febrero de 1987 que la denegaba nuevamente; en su lugar ordena la sentencia que se incoe el procedimiento del articulo 25.2 en relación con los artículos 15 a 17 del Reglamento de Edificación Forzosa y Registro Municipal de Solares de 5 de marzo de 1964, con el fin de que en el mismo se dilucide y decida si hay que declarar o no declarar incumplida aquella obligación de edificar.

SEGUNDO.- Los apelantes discrepan de la sentencia en los dos siguientes extremos: a) la sentencia de instancia debió declarar la inadmisibilidad del recurso contencioso-administrativo porque la resolución municipal expresa de fecha 2 de febrero de 1987 que denegaba el recurso de reposición entablado por don Pedro F.P. no ha sido recurrida, y por ello es un acto consentido y firme que según el artículo 40. a) de la Ley de la Jurisdicción es inimpugnable; b) la incoación del expediente a que se refiere el artículo 25 es potestativa del Ayuntamiento; $y$ en todo caso la sentencia ha incurrido en incongruencia porque sólo se recurrió la denegación presunta y no la expresa, en tanto que la sentencia también anuló ésta; y también es incongruente 
porque la demanda solicita se declare incumplida la obligación de edificar y no se refiere a la denegación de incoación del expediente.

TERCERO. - Ni una ni otra alegación poseen la más mínima enjundia revocatoria. Respecto a la primera, ciertamente, el Ayuntamiento denegó expresamente con fecha 2 de febrero de 1987 el recurso de reposición que había sido presentado en 14 de noviembre de 1986 contra la Resolución de 22 de septiembre de ese mismo año que denegaba "la solicitud de incoación de expediente para declarar incumplida la obligación de edificar... ". Pero como se reconoce abiertamente en los escritos de alegaciones por las partes apelantes esta expresa resolución denegatoria no fue notificada al solicitante; sin que tal defecto pueda suplirse por una mera presunción de que debió tener conocimiento de la misma al examinar el expediente. De manera que habiéndose quebrantado por el Ayuntamiento los artículos 79 y 23 de la Ley de Procedimiento Administrativo con tal omisión, pretender extraer de esta circunstancia una inadmisibilidad del recurso, por otra parte no alegada en la primera instancia, es algo que limita, si no invade y se impregna del abuso procesal. En cuanto a la segunda de semejantes alegaciones, basta leer el suplico del escrito del señor F.P., de fecha 7 de octubre de 1955 en el expediente administrativo, para entender que lo califica de denuncia, empleando el término que expresa el art. 25 del Reglamento de Edificación Forzosa; y citando ese precepto solicita que se dicte acuerdo, con base en el mismo, que declare incumplida la obligación de edificar. Congruente con tal petición es la resolución del Ayuntamiento de 22 de septiembre que deniega la solicitud de incoación de expediente. Esa misma congruencia persiste en el escrito de interposición del recurso contencioso-administrativo, y se extiende hasta la Sentencia que pone fin a la primera instancia. Por tanto no hay incongruencia alguna en la Sentencia ni en virtud de esta alegación ni por mor de la anterior. Por último es del todo ajustado a derecho el fallo de la Sentencia en cuanto ordena la incoación del expediente; y con ello no hace más que aplicar el artículo 25 antes citado que, en su párrafo 2, claramente dice que, para declarar incumplida la obligación de edificar, bien sea por propia iniciativa, a requerimiento del órgano urbanístico competente o en virtud de denuncia -como aqui ha acaecído-es preciso tramitar un expediente al que se aplicará en lo pertinente lo dispuesto en los artículos 15 a 17. Al no hacerlo así el Ayuntamiento ha hecho caso omiso de la aplicación, en lo pertinente, de tales preceptos."

(Sentencia de 15 de mayo de 1990. Ar. 4074. ESTEBAN ALAMO.) 
